\title{
Long-term impacts of mid-Holocene drier climatic conditions on Bolivian tropical dry forests
}

\author{
Heather J. Plumpton $^{a *}$, Francis E. Mayle ${ }^{\mathrm{a}}$, Bronwen S. Whitney ${ }^{\mathrm{b}}$ \\ ${ }^{a}$ School of Archaeology, Geography and Environmental Science, University of Reading, United Kingdom \\ ${ }^{\mathrm{b}}$ Department of Geography and Environmental Sciences, Northumbria University, United Kingdom \\ *Corresponding author at: Russell Building, School of Archaeology, Geography and Environmental Science (SAGES), University of Reading, Whiteknights, \\ P.O. Box 227, Reading RG6 6DW, Berkshire, United Kingdom. E-mail address: hjplumpton@ gmail.com (H.J. Plumpton).
}

(Received November 26, 2018; Revised June 28, 2019; AcCePted July 29, 2019)

\begin{abstract}
The Bolivian Chiquitano dry forest is the largest block of intact seasonally dry tropical forest in South America and is a priority ecoregion for conservation due to its high threat status. However, the long-term impacts of drier climatic conditions on tropical dry forests are not well understood, despite climate models predicting increased droughts over Bolivia in the coming century. In this paper, we assess the impacts of drier climatic conditions during the mid-Holocene on the Bolivian Chiquitano tropical dry forest using fossilised pollen, phytoliths, macro-charcoal, and geochemical proxies from a sediment core from a large lake (Laguna Mandioré) on the Bolivia-Brazil border. Our results show that drier climatic conditions during the midHolocene caused a local-scale, ecotonal expansion of upland savannah at the expense of dry forest. Interaction between drier climatic conditions and fire regime likely exerted a stronger control over the position of the dry forest-savannah ecotone than edaphic factors. However, the majority of the dry forest within the lake catchment maintained a closed canopy throughout the drier conditions of the mid-Holocene, despite floristic turnover towards more drought-tolerant taxa. These findings imply overall resilience of the Chiquitano dry forest biome to future drought, albeit with floristic changes and upland savannah encroachment at ecotones.
\end{abstract}

Keywords: Tropical dry forest; Savannah; Drought; Forest-savannah ecotone; Mid-Holocene; Bolivia; Pollen; Phytoliths

\section{INTRODUCTION}

Dry forests are the most threatened tropical forest type in South America, with only $10 \%$ of their cover remaining in tropical America (Banda-R et al., 2016). Their threatened status is largely due to their presence on fertile soils suitable for agriculture, which has led to higher rates of deforestation and fragmentation compared with humid rainforests in South America, which tend to grow on less fertile soils (Janzen, 1988; DeFries et al., 2004). Tropical dry forests are also less well studied than humid evergreen forests, such as the Amazon rainforest, perhaps due to their lower species richness (Banda-R et al., 2016). However, the biological significance and unique evolutionary history of the dry forest biome has become increasingly apparent in recent years, leading to greater prioritisation for conservation (Banda-R et al., 2016).

Cite this article: Plumpton, H. J., Mayle, F. E., Whitney, B. S. 2020. Long-term impacts of mid-Holocene drier climatic conditions on Bolivian tropical dry forests. Quaternary Research 93, 204-224. https://doi.org/ 10.1017/qua.2019.55
Dry forests occur in highly seasonal climates with a pronounced dry period where rainfall is less than $1600 \mathrm{~mm} /$ year with at least 5-6 months receiving less than $100 \mathrm{~mm}$ (Gentry, 1995). They are deciduous to semideciduous, closed-canopy ecosystems with a minor grass component in the understorey (Pennington et al., 2000). The focus of this paper is on the Chiquitano dry forest of eastern Bolivia, which is located between humid evergreen Amazonian rainforests to the north, dry Chaco thorn-scrub to the south, and Pantanal seasonally flooded savannahs to the east (Killeen and Schulenberg, 1998; Killeen et al., 2006). Interspersed among this dry forest are patches of upland (cerrado) savannah. The Chiquitano dry forest is the largest block of intact seasonally dry tropical forest in South America and has been identified as a priority ecoregion for conservation, due to its highly threatened status (Olson et al., 2001). In addition to the pressures from deforestation and fragmentation, the dry forest may also be threatened by climate change, as most climate models predict reduced precipitation for tropical South America in the coming century (Malhi et al., 2008, 2009; Duffy et al., 2015; Sánchez et al., 2015). In particular, in southern 
Amazonia, models predict a late onset of the rainy season and a longer dry season (Marengo et al., 2014) and a 30\% reduction in precipitation over the Pantanal basin (Marengo et al., 2016).

Dry forest and upland (cerrado) savannah grow under similar climatic conditions and typically have a mosaic distribution governed by edaphic factors. Dry forests tend to occur on calcareous soils of intermediate to high fertility (Nunes da Cunha et al., 2007), whereas cerrado savannahs tend to occur on shallower soils with poor fertility (Sarmiento and Monasterio, 1975; Jardim et al., 2003) and low calcium levels (Ratter et al., 1988; Dubs, 1992). However, the relationships among edaphic factors, climate change, and fire regime in controlling dry forest-savannah ecotonal dynamics are poorly understood. Drier climatic conditions may indirectly influence dry forest-savannah ecotones by driving an increase in fire frequency, in turn leading to upland savannah expansion due to the greater fire tolerance/adaptation of upland savannah tree taxa compared with dry forest tree taxa (Pennington et al., 2009). While fire has been shown to be a persistent feature of the Chiquitano dry forest throughout the Holocene (Power et al., 2016), the sensitivity of the Chiquitano dry forest-savannah ecotone to the combination of drought and fire has not been explored. Furthermore, a study by Power et al. (2016) suggests that the primary driver of floristic turnover within the Chiquitano dry forest during the Holocene may have been climate, as some taxa are better adapted to water stress than others. Therefore, it is possible that drier climatic conditions may cause floristic turnover within the forest, even if full biome turnover is not achieved (i.e., replacement of dry forest by upland savannah). However, because the Power et al. (2016) study is based on a single lake sediment core, the broader-scale implications of this study are open to question. More palaeoecological records are needed to better elucidate the long-term, potentially complex interactions among tropical dry forests, climate, fire, and edaphic factors.

During the mid-Holocene, between 9000 and $3000 \mathrm{cal} \mathrm{yr}$ BP, the Southern Hemisphere tropics of South America experienced significantly drier climatic conditions, potentially driven by a weakening of the South American summer monsoon, linked to changes in solar insolation (Cruz et al., 2009; Prado et al., 2013). This drier climatic period is evident in palaeoclimate records from the Andes to the lowlands of Bolivia and Brazil. In the Andes, lake level at Laguna Titicaca dropped to $100 \mathrm{~m}$ below present levels between 6000 and 5000 cal yr BP (Baker et al., 2001). Dust and pollen records from ice cores from Sajama Mountain in Bolivia (Thompson, 1998; Reese et al., 2013) and oxygen isotopes from sediment records from Laguna Junin in Peru (Seltzer et al., 2000) and from Laguna Pamachoca in Peru (Bird et al., 2011) confirm the mid-Holocene drier period in the Andes. Pollen records from Lagunas Chaplin and Bella Vista in eastern Bolivia confirm that the mid-Holocene drier period extended to the lowlands (Burbridge et al., 2004). In the Pantanal lowlands, this period is confirmed by a speleothem record from Jaraguá Cave (Novello et al., 2017); phytolith and sponge spicule records from Laguna Negra (Rasbold et al., 2019); and pollen, geochemical, sedimentary, and Pediastrum records from Laguna La Gaiba at the eastern margin of the Chiquitano dry forest (Whitney et al., 2011; McGlue et al., 2012; Whitney and Mayle, 2012; Metcalfe et al., 2014).

Records from Laguna La Gaiba also provide evidence that the mid-Holocene drier climate probably took the form of a longer dry season rather than lower mean annual precipitation (Whitney et al., 2011). As this is the same pattern of precipitation change that is predicted for the region by climate models (Marengo et al., 2014; Duffy et al., 2015), it provides a potential analog for the impacts of future climate changeinduced droughts in the region. The long-term impacts of the mid-Holocene drier climate on the dry forest and ecotone with upland savannah may therefore provide insights into the likely impact of a predicted future drier climate upon these threatened tropical forests.

The responses of tropical dry forests and upland savannahs to the mid-Holocene drier period are not well understood, partly due to the lack of sufficiently old, permanent lakes within the dry forest biome from which palaeo-vegetation records can be drawn. In the Chiquitano dry forest of Bolivia, there are only three lake sites for which palaeo-vegetation records for the Holocene have been published-Laguna Yuguarú in the central lowlands of Bolivia (Taylor et al., 2010) and Lagunas Negra and La Gaiba at the eastern edge of the Chiquitano forest on the Bolivian-Brazilian border (Whitney et al., 2011; Rasbold et al., 2019). As the record from Yuguarú only covers the last $6000 \mathrm{yr}$, it does not span the full duration of the mid-Holocene drier period, and therefore precludes thorough investigation of the impacts of this period on the dry forest vegetation at this site. The sponge spicule and phytolith record from Laguna Negra spans the Pleistocene to the present, providing an environmental reconstruction of flooding in the Pantanal, but not a vegetation reconstruction for the dry forest (Rasbold et al., 2019). Laguna La Gaiba is the only palaeoecological record in the Chiquitano dry forest region that spans the onset and termination of the mid-Holocene drier period. The 45,000 year Laguna La Gaiba record shows that dry forest has been present since $\sim 19,500$ cal yr BP, maintaining closed-canopy forest throughout, with some floristic shifts during the mid-Holocene drier period towards more drought-tolerant taxa (Whitney et al., 2014).

However, the degree to which the fossil pollen record from Laguna La Gaiba-a single core from a large lake with a complex catchment of dry forest and seasonally flooded savannah wetlands-represents a robust signature of the broader-scale vegetation history of the Chiquitano dry forest is uncertain. Furthermore, the scarcity of upland savannah in the lake catchment means that the pollen record of this site is unlikely to be sensitive to local-scale dry forest-upland savannah ecotonal dynamics. Additional palaeoecological records, closer to the forest-savannah ecotone, are therefore needed to obtain a more robust understanding of the impact of lower mid-Holocene precipitation upon this dry forest ecosystem. 
The aim of this paper is to produce a Holocene palaeoecological record from Laguna Mandioré-a dry forest lake $20 \mathrm{~km}$ to the south of Laguna La Gaiba-to improve understanding of the long-term impacts of drier climatic conditions during the mid-Holocene upon the Bolivian Chiquitano tropical dry forest. Specifically, we will test three hypotheses. First, due to the edaphic constraints on the position of the dry forest-upland savannah ecotone, we hypothesise that the ecotone remained static during the mid-Holocene drier period. Second, we hypothesise that the dry forest maintained a closed canopy throughout the mid-Holocene drier period, with some floristic changes, as shown at Laguna La Gaiba (Whitney et al., 2011, 2014). Third, we hypothesise that the dominant control on vegetation changes in the Chiquitano dry forest during the Holocene is climate, rather than fire, as shown at Laguna La Gaiba (Power et al., 2016).

\section{STUDY AREA AND SITE SELECTION}

The study area of eastern lowland Bolivia is covered to a large extent by Chiquitano tropical dry forests, which occupy a transition zone between Amazonian humid evergreen forests to the north and dry Chaco thorn-scrub and savannah to the south and east, respectively (Killeen and Schulenberg, 1998; Killeen et al., 2006; Fig. 1).

The Chiquitano dry forests are characterized by pronounced seasonality in rainfall distribution, being semideciduous during the dry season, with the degree of deciduousness increasing as rainfall declines. They are tree-dominated, closed-canopy ecosystems, with a minor grass component, tending to have a smaller size structure and thornier species than humid evergreen forests (Pennington et al., 2000). The woody flora tends to be dominated by Fabaceae and Bignoniaceae (with particularly high abundances of Tabebuia), with floristic variation according to proximity to ecotones and type of geological substrate. Additional key taxa that are common across the biome include: Anacardiaceae (Spondias), Achatocarpaceae (Achatocarpus), Malvaceae (Ceiba, Chorisia), Boraginaceae (Cordia), Cactaceae (Cereus), and Cochlospermaceae (Cochlospermum) (Killeen et al., 2006).

The eastern limit of the Chiquitano dry forest coincides broadly with the Paraguay River and the Bolivian-Brazilian border, to the east of which lies the Pantanal-the largest tropical wetland in the world $\left(\sim 135,000 \mathrm{~km}^{2}\right)$-which is formed by flooding of the Paraguay River and its tributaries (Fig. 1). The vegetation of the Pantanal is a heterogeneous mosaic of xeric, mesic, and seasonally inundated plant communities, controlled by edaphic factors, topography, and flooding (Ratter et al., 1988; Dubs, 1992; Hamilton, 2002; Alho, 2005; Nunes da Cunha et al., 2007). The species composition is a mixture of the surrounding ecosystems, with some Amazonian humid evergreen forest species occurring in gallery forests, dry forest species occurring on raised levees, cerrado savannah species occurring in higherelevation areas, and seasonally flooded low-elevation areas containing seasonally inundated savannahs (Alho, 2005) the dominant vegetation type of the Pantanal. The upland savannah habitat of the Amolar hills (located near Laguna La Gaiba and Laguna Mandioré; Figs. 1 and 2) is typical of the Brazilian cerrado and is dominated by the following species: Caryocar brasiliense, Qualea grandiflora, Tabebuia caraiba, Diptychandra glabra, and Hymenaea stigonocarpa (Prance and Schaller, 1982). In flooded areas of the Pantanal and shorelines of these two lakes, key herbaceous species include: Pontederia cordata, Eichhornia crassipes, Thalia geniculata, and Cyperus giganteus (Prance and Schaller, 1982). The Pantanal wetlands are linked to both Laguna Mandioré and Laguna La Gaiba via the Paraguay River, which floods annually, overflowing into the surrounding wetlands (Hamilton, 2002; Figs. 1 and 2).

The study site is Laguna Mandioré-a large, shallow, flatbottomed lake $\left(\sim 152 \mathrm{~km}^{2}, 92 \mathrm{~m}\right.$ above seal level [asl], depth of 4-6 m), 20 km south of the southern shore of Laguna La Gaiba-located along a fault between the Bolivian Chiquitano semideciduous dry forest to the west and the Brazilian Pantanal wetlands to the east. On the eastern shore of Laguna Mandioré, dry forest grades into cerrado upland savannah as altitude increases, and soils become thinner up a series of large hills (Amolar hills, $\sim 900 \mathrm{~m}$ asl) that separate the majority of the lake margin from the Pantanal wetlands (Fig. 2). The geology of the surrounding area is a complex of coalesced alluvial fans from incoming rivers across the Pantanal, as well as outcrops of crystalline rock, limestone, and iron and manganese oxides that form the Amolar hills ( $900 \mathrm{~m}$ asl) (Hamilton, 2002). Laguna Mandioré is a highenergy lake with significant wave action and potential for resuspension of sediment. The annual flood pulse during the wet season is not over land but via channels connected to the Paraguay River, the headwaters of which are formed by seasonal rains over the Pantanal basin (Hamilton, 2002). The two primary channels are located at the southeastern and northern edges of the lake. This flood pulse brings an organic-rich input to the lake. These river channels also act to drain the lake into hydrological isolation during the dry season (McGlue et al., 2011).

Laguna La Gaiba is also a large, shallow lake $\left(\sim 90 \mathrm{~km}^{2}\right.$, depth of 4-6 m) split into two subbasins: the deeper southern basin is surrounded to the south by hills predominantly covered by Chiquitano dry forest; the shallower northern basin merges into the Pantanal wetlands (Whitney et al., 2014; Figs. 1 and 2). The specific site of connection to the Paraguay River is a channel at the eastern edge of the northern subbasin, which produces a large sandy fan. Biogeochemical characteristics are similar to those of Laguna Mandioré, except that Laguna La Gaiba has lower productivity with lower concentrations of organic carbon, nitrogen, and biogenic silica (McGlue et al., 2011). In contrast to the area surrounding Laguna Mandioré, however, the hills bordering Laguna La Gaiba are of lower elevation and largely covered by dry forest.

Due to the proximity of Lagunas La Gaiba and Mandioré, a comparison of palaeoecological records from these lakes should clarify the spatial scale they represent and potentially constrain the spatial scale of any Holocene ecotonal shifts. 

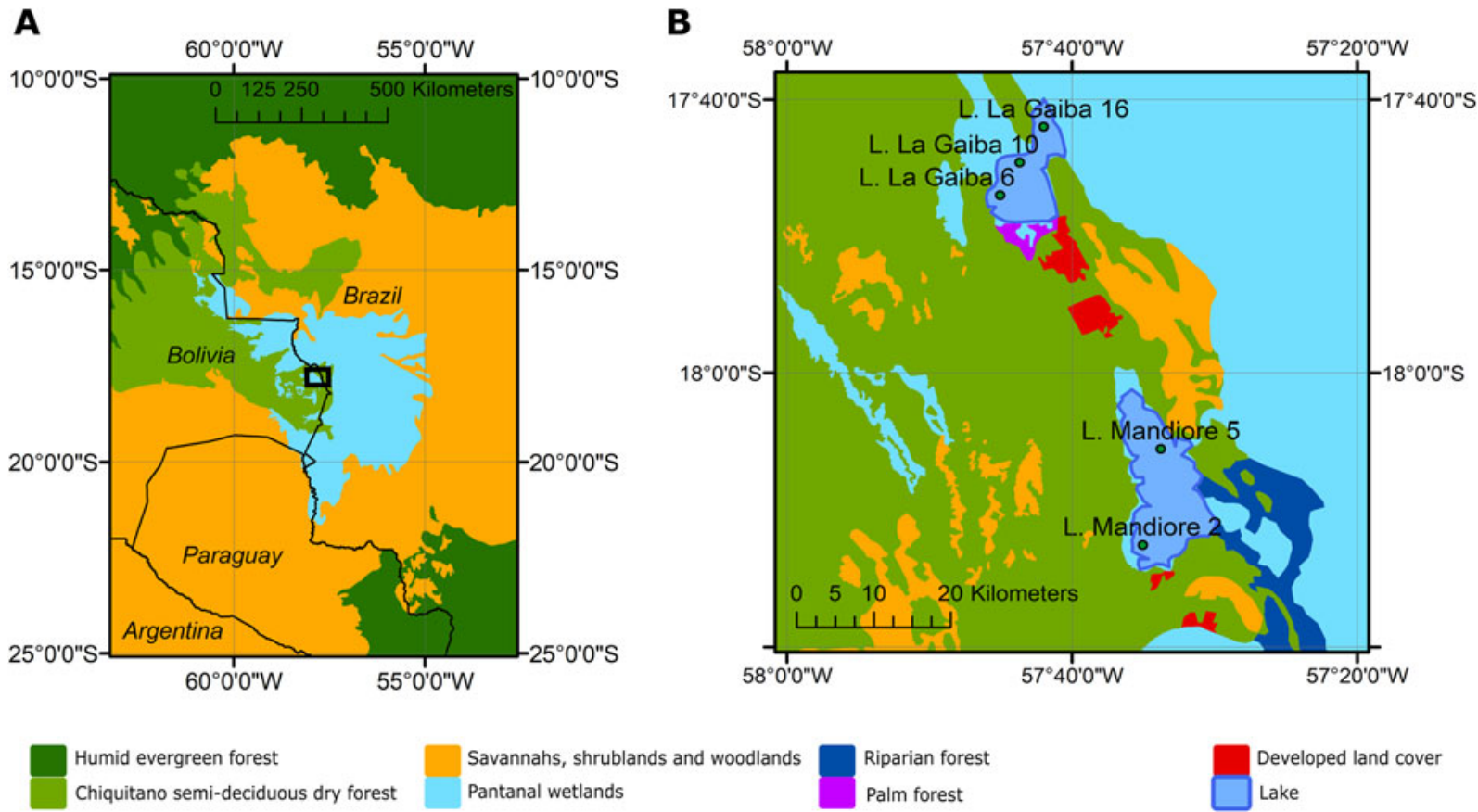

Figure 1. (color online) (A) A map of the study region with black box outlining study area. (B) Zoomed-in map of the study area with vegetation types surrounding Lagunas Mandioré and La Gaiba and the multiple surface-sample locations from each lake.

\section{Approach}

Lagunas Mandioré and La Gaiba are both situated within complex catchments surrounded by multiple terrestrial, aquatic, and semiaquatic ecosystems that are possible sources of the pollen and phytoliths deposited within their sediments. Therefore, we first investigate potential pollen and phytolith sources by comparing modern assemblages from multiple surface samples across both lakes. These results will inform the interpretation of the pollen and phytolith records from Laguna Mandioré, which will enable an assessment of the long-term impacts of the mid-Holocene drier climatic period on the surrounding dry forest and nearby dry forest-upland savannah ecotone. The use of phytoliths will allow the differentiation of Poaceae subfamilies (Piperno, 2006) at key horizons in the pollen record and will therefore assist with differentiating dry forest understorey from upland and wetland savannah signals. It will also provide a more local-scale vegetation signal than pollen (Piperno, 2006; Whitney et al., 2013; Carson et al., 2015).

\section{METHODS}

\section{Field methods}

A sediment core of $4.5 \mathrm{~m}$ consisting of overlapping 1-m sections was collected by FEM in 2001 from the northern end of Laguna Mandioré (core site 5: $18^{\circ} 5^{\prime} 30.60^{\prime \prime} \mathrm{S}$, $\left.57^{\circ} 33^{\prime} 45.60^{\prime \prime} \mathrm{W}\right), \sim 2 \mathrm{~km}$ from the Amolar hill formation (Figs. 1 and 2), using a drop-hammer, modified Livingstone piston corer from an anchored floating platform (Colinvaux et al., 1999). An overlapping surface-sediment core, including the sediment-water interface, was collected using a 5-cm-diameter Perspex tube and piston. An additional surfacesediment core was collected from the southwestern portion of the lake (core site $2: 18^{\circ} 12^{\prime} 32.00^{\prime \prime} \mathrm{S}, 57^{\circ} 35^{\prime} 2.00^{\prime \prime} \mathrm{W}$ ). The surface core was split in the field into $1 \mathrm{~cm}$ increments and placed into watertight plastic tubes. The Livingstone cores were shipped in their sealed aluminium tubes. All samples were kept in cold storage at $4^{\circ} \mathrm{C}$.

Three surface-sediment samples were analysed from Laguna La Gaiba: core site 6 in the west of the south basin $\left(17^{\circ} 47^{\prime} 0.00^{\prime \prime} \mathrm{S}, 57^{\circ} 45^{\prime} 2.00^{\prime \prime} \mathrm{W}\right)$, core site 10 in the north of the south basin $\left(17^{\circ} 44^{\prime} 36.50^{\prime \prime} \mathrm{S}, 57^{\circ} 43^{\prime} 40.00^{\prime \prime} \mathrm{W}\right)$, and core site 16 in the north basin $\left(17^{\circ} 41^{\prime} 60.00^{\prime \prime} \mathrm{S}, 57^{\circ} 41^{\prime} 59.00^{\prime \prime} \mathrm{W}\right)$ (Figs. 1 and 2). Core site numbers refer to those originally published in Whitney et al. (2011).

\section{Laboratory methods}

Fossil pollen and phytolith analyses were undertaken to reconstruct the vegetation history of the Laguna Mandiore site. Sediment samples measuring $1 \mathrm{ml}$ were processed for fossil pollen using the standard protocol (Faegri and Iversen, 1989). Fossil pollen identification was conducted using the tropical pollen reference collection at the University of Reading Tropical Palaeoecology Research laboratory, which contains more than 1000 specimens and published pollen reference literature (Roubik and Moreno, 1991; Colinvaux et al., 1999). Terrestrial pollen counts of 300 grains were obtained for each sample, including both Poaceae and Cyperaceae. The sampling resolution for pollen varies between 150 yr during the mid-Holocene up to $1200 \mathrm{yr}$ in the early Holocene $(\mathrm{N}=26)$. 

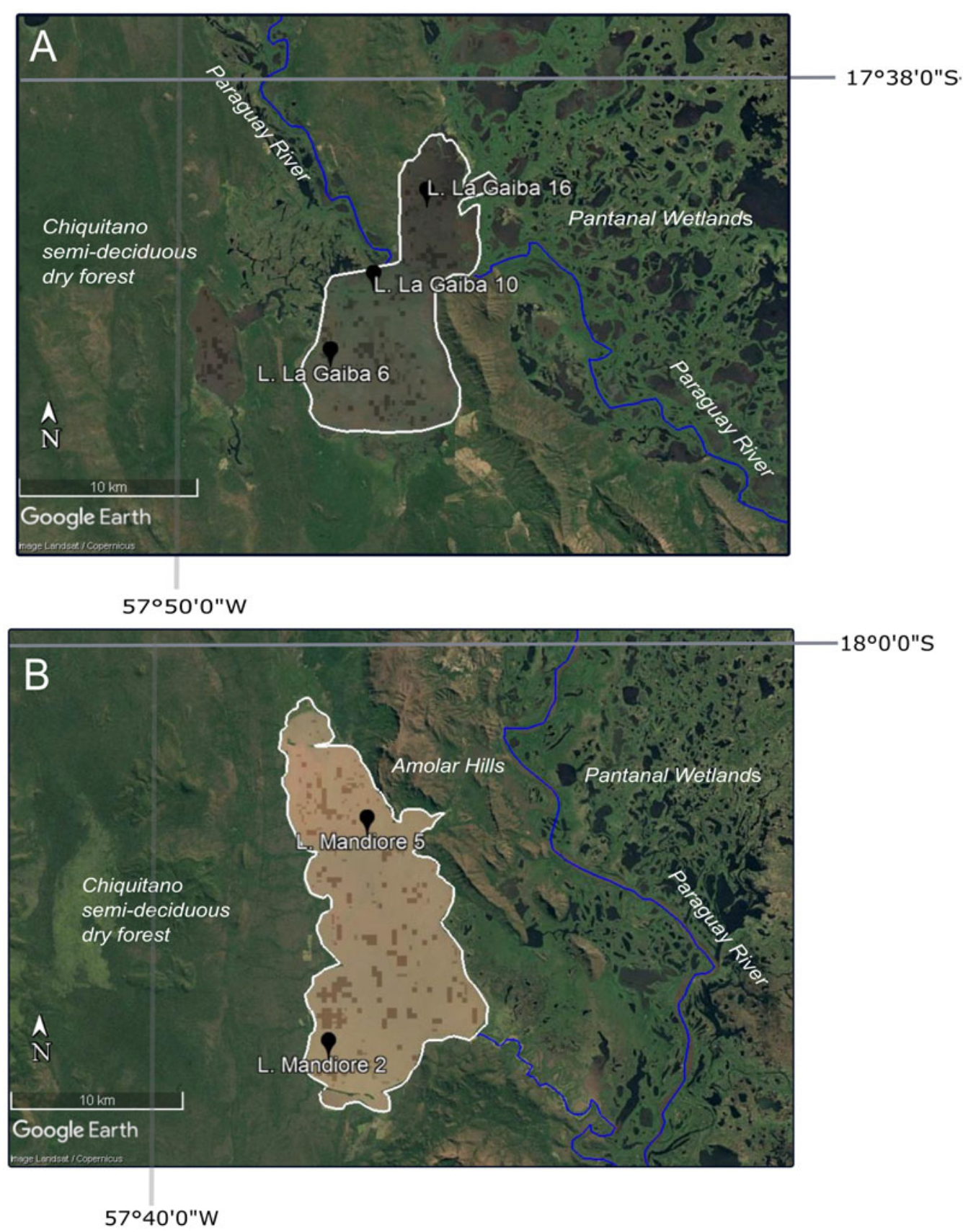

Figure 2. Google Earth imagery of lake sites with core site locations shown by black markers, lake outline shown by the white line, Paraguay River shown by blue lines, and ecosystems labelled. (A) Laguna La Gaiba; (B) Laguna Mandioré. (For interpretation of the references to color in this figure legend, the reader is referred to the web version of this article.)

Sediment samples of $3 \mathrm{ml}$ were processed for phytolith analysis using the standard wet-sediment technique (Piperno, 2006). Phytolith extraction was conducted using the wet oxidation method involving nitric acid heated to $90^{\circ} \mathrm{C}$ as described in Piperno (2006). Wet-sediment samples of $3 \mathrm{ml}$ were obtained from each horizon to allow for fractionation during processing into " $\mathrm{A}$ " $(<53 \mu \mathrm{m})$ and "C" $(53-250 \mu \mathrm{m})$ fractions (Piperno, 2006). A-fraction slides were counted at $400 \times$ magnification, and a minimum sum of 200 diagnostic phytoliths was counted for each sample. C-fraction slides were scanned at $100 \times$, with identifications conducted at
$400 \times$ magnification. All diagnostic phytoliths on the C-fraction slides were counted. Phytolith identification was carried out with reference to the University of Reading tropical phytolith reference collection, which contains modern specimens from 152 species, and photographs of the University of Exeter phytolith reference collection, which contains more than 500 modern neotropical species. Published phytolith reference atlases for the Neotropics, tropical Africa, Asia, and Australasia were also consulted (Kondo et al., 1994; Boyd et al., 1998; Piperno and Pearsall, 1998b, 1998a; Runge, 1999; Wallis, 2003; Lu and Liu, 2003; Piperno, 2006; Iriarte 
and Paz, 2009; Mercader et al., 2009, 2011; Dickau et al., 2013; Watling and Iriarte, 2013; Watling et al., 2016). The sampling resolution for phytoliths varies from $1000 \mathrm{yr}$ in the mid-Holocene up to $2000 \mathrm{yr}$ in the early and late Holocene $(\mathrm{N}=7)$.

To reconstruct past changes in fire regime, macroscopic charcoal was analysed from $1 \mathrm{ml}$ of wet sediment $(\mathrm{N}=37)$, treated with hot sodium hexmetaphosphate and sodium hydroxide, and sieved into $>100 \mu \mathrm{m}$ and $>180 \mu \mathrm{m}$ fractions. All charcoal particles were counted for both fractions and identified as being from herbaceous or woody taxa under a stereo microscope (Whitlock and Larsen, 2001).

Loss-on-ignition (LOI) at $550^{\circ} \mathrm{C}$ and $950^{\circ} \mathrm{C}$ was performed on $1 \mathrm{ml}$ of wet sediment at $4 \mathrm{~cm}$ resolution $(\mathrm{N}=$ 79), to determine organic and carbonate content, respectively (Heiri et al., 2001). Wet-sediment samples of $1 \mathrm{ml}$ were dried and ground to a fine powder and treated with $\mathrm{HCl}$ to remove carbonates before measurement of $\mathrm{C}, \mathrm{N}$, and $\delta^{13} \mathrm{C}$ (Harris et al., 2001). Total $\% \mathrm{C}$ and $\% \mathrm{~N}$ were measured on a Flash 2000 to determine $\mathrm{C} / \mathrm{N}$ ratios $(\mathrm{N}=81) . \delta^{13} \mathrm{C}$ of bulk sediment was measured with a ThermoFisher Scientific Delta V Advantage mass spectrometer $(\mathrm{N}=81)$. Total $\% \mathrm{C}$ and $\% \mathrm{~N}$ were calculated relative to standard reference material, aspartic acid and laboratory soil standard QC. Replicate analysis of laboratory reference material QC yielded the following precision data $\left(n=14, \pm \sigma_{n-1}\right): 0.13 \%$ and $0.04 \%$ for $\% C$ and $\% N$, respectively. The $\delta^{13} \mathrm{C} /{ }^{12} \mathrm{C}$ ratio was calculated relative to standard reference materials polyethylene $(\mathrm{CH} 7)$, sucrose (CH6), and L-glutamic acid (USG40) and reported as per mille (\%o) deviations from VPDB standard. Replicate analysis of standard reference materials $\mathrm{CH} 7, \mathrm{CH}$, and USG40 yielded the following precision data $\left(\mathrm{n}=13, \pm \sigma_{\mathrm{n}-1}\right)$ : $0.23 \%$ o $0.01 \%$, and $0.04 \%$ o, respectively. $\mathrm{C} / \mathrm{N}$ ratios were multiplied by 1.167 to get atomic $\mathrm{C} / \mathrm{N}$ for comparison with established ratios (Meyers and Teranes, 2001). X-ray fluorescence (XRF) analysis was conducted using a portable X-ray fluorescence Thermo Scientific Niton 3L3t GOLDD at 1 $\mathrm{cm}$ resolution on intact long sediment cores $(\mathrm{N}=268)$. Analysis was not possible for the surface core $(0-54 \mathrm{~cm})$, as insufficient sediment was available. XRF data measured as counts per second (cps) are presented as ratios throughout this paper (Francus et al., 2009). Lithological descriptions of the sediments were conducted using the Munsell colour chart.

Radiocarbon dates were obtained from bulk lake sediment, due to the absence of sufficient terrestrial plant macrofossils or macro-charcoal particles for dating. Two dates were obtained from Beta Analytic and five further Holocene dates were granted by the Natural Environment Research Council radiocarbon facility (allocation number 2038.1016).

\section{Numerical analyses}

Frequency and stratigraphic plots for pollen, phytoliths, and charcoal were created using version 1.7 of the $\mathrm{C} 2$ software (Juggins, 2016) and edited in Inkscape 0.92.3. Stratigraphic diagrams for geochemical data were created in the rioja 0.9-15.1 package in $\mathrm{R}$ v. 3.4.1 and edited in Inkscape
0.92.3. The age-depth model was built using Bacon 2.3.4 package in R v. 3.4.1 (Blaauw and Christen, 2011) and the IntCal13 calibration curve (Reimer et al., 2013), due to the strong influence of the South American summer monsoon and Northern Hemisphere air masses on atmospheric circulation in our study region (Marsh et al., 2018).

A constrained clustering analysis (CONISS) with Euclidean distances (Grimm, 1987) was carried out on the pollen data, and statistically significant pollen zones were determined using the broken stick model (Bennett, 1996) in the rioja 0.9-15.1 package (Juggins, 2017) in R v. 3.4.1. Palynological richness was determined using rarefaction analyses to control for the influence of count size on pollen sums (Birks and Line, 1992) using the vegan 2.5-2 package (Oksanen et al., 2018) in R v. 3.4.1.

\section{Map production}

Maps of the ecosystems surrounding the lake site were created using ArcGIS 10.4 (Fig. 1). A vegetation classification of our study area, based on Landsat imagery, was provided by the Museo de Historia Natural Noel Kempff Mercado, Santa Cruz, Bolivia, in 2015. This map is overlaid on the WWF terrestrial ecoregions of the world, adapted from Olson et al. (2001). Additional maps of the lake sites (Fig. 2) were created using Google Earth Pro imagery and Inkscape 0.92.3.

\section{RESULTS}

\section{Modern pollen and phytoliths at Lagunas Mandioré and La Gaiba}

\section{Modern pollen}

The two surface samples from Laguna Mandioré (2 and 5) contain similar pollen assemblages, dominated by Poaceae pollen at $48 \%-56 \%$ with pollen richness of 24 (Fig. 3). Both samples contain consistent levels of Anadenanthera (4\%), Alchornea (3\%), Arecaceae (2\%), and Curatella americana $(1 \%)$ pollen. Cyperaceae and total Moraceae/Urticaceae pollen abundances are higher at Mandioré $2(19 \%$ and $11 \%$, respectively) than at Mandiore 5 (9\% and 5\%, respectively), whereas Astronium and Celtis pollen abundances are higher at Mandioré 5 (3\% and 5\%, respectively) than at Mandioré 2 (1\% and 1\%, respectively) (Fig. 3).

The relative abundances of pollen types were more variable between the surface samples from Laguna La Gaiba $(6,10$, and 16) than between the Laguna Mandioré surface samples. La Gaiba 6 and 10 are more similar to each other than $\mathrm{La}$ Gaiba 16 (Fig. 3). Pollen richness at La Gaiba 6 and 10 is similar to that at the Mandiore sites (26 and 25, respectively), while richness at La Gaiba 16 is considerably lower at 18 . La Gaiba 16 shows higher abundance of Cyperaceae pollen (34\% compared with 21\%-23\% at La Gaiba 6 and 10, respectively) and lower abundance of arboreal pollen ( $6 \%$ compared with $18 \%-23 \%$ at La Gaiba 6 and 10, respectively), with both Astronium and Acalypha pollen absent. 


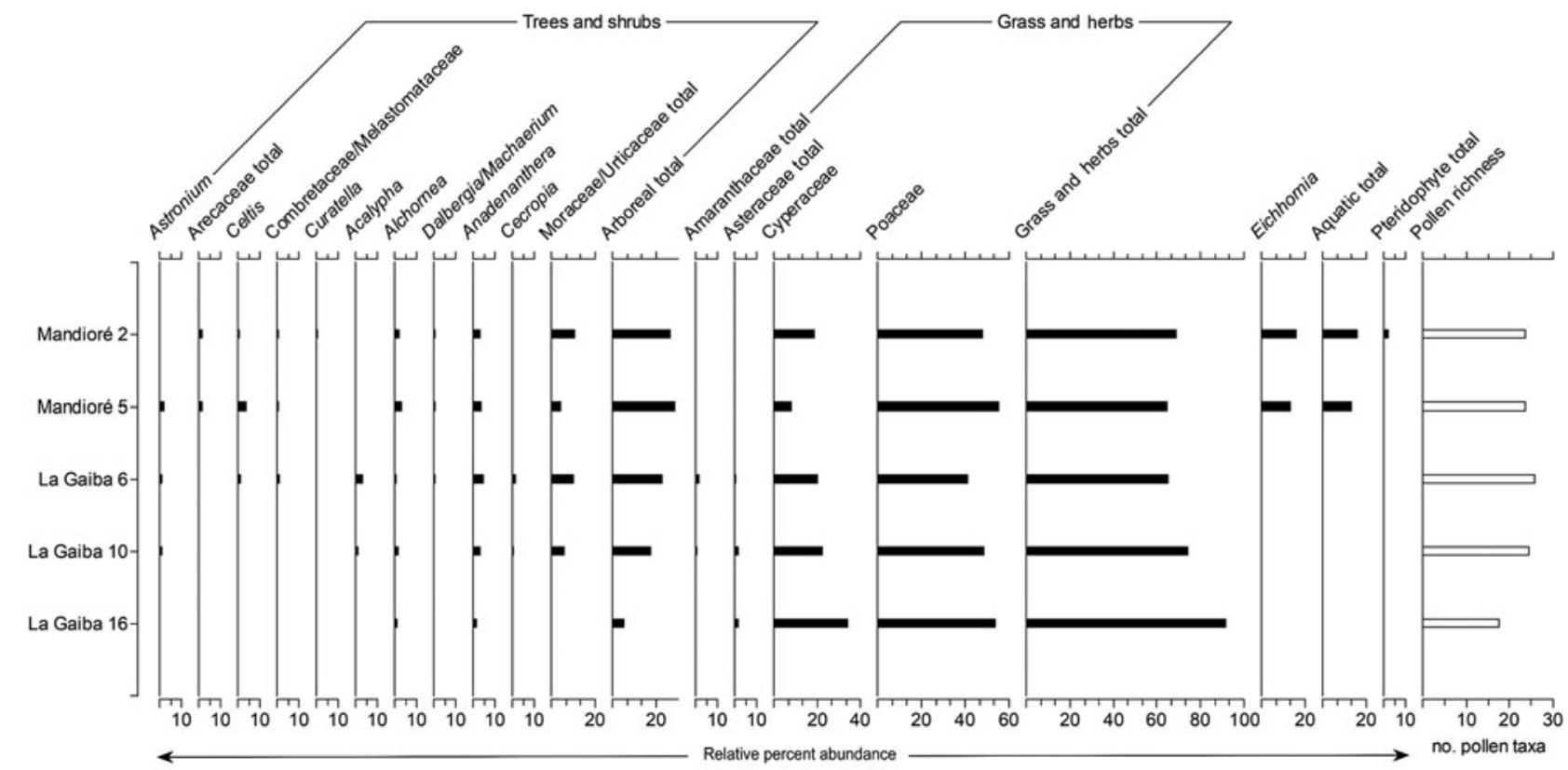

Figure 3. Summary pollen diagram from two Laguna Mandioré surface samples and three Laguna La Gaiba surface samples. Pollen presented as percentage of terrestrial sum.

Overall, the modern pollen assemblages are similar across the surface samples from the two lakes, except for La Gaiba 16. Mandioré 2 and 5 and La Gaiba 6 and 10 all show similar total arboreal pollen abundances (18\%-29\%) including Astronium, Anadenanthera, Moraceae/Urticaceae, Alchor$n e a$, and Celtis pollen, whereas La Gaiba 16 only contains pollen of Alchornea and Anadenanthera as arboreal taxa. La Gaiba 16 also contains higher Cyperaceae and Poaceae pollen abundances than the other four surface samples. Pollen of Curatella americana and the aquatic plant Eichhornia are only present in the Mandioré samples.

\section{Modern phytoliths}

The phytolith assemblages from the surface samples at Mandiore 2 and 5 are broadly consistent with each other, with grass and herb total ranges from $73 \%$ to $77 \%$ and arboreal totals from $22 \%$ to $26 \%$ (Fig. 4). However, woody eudicot-

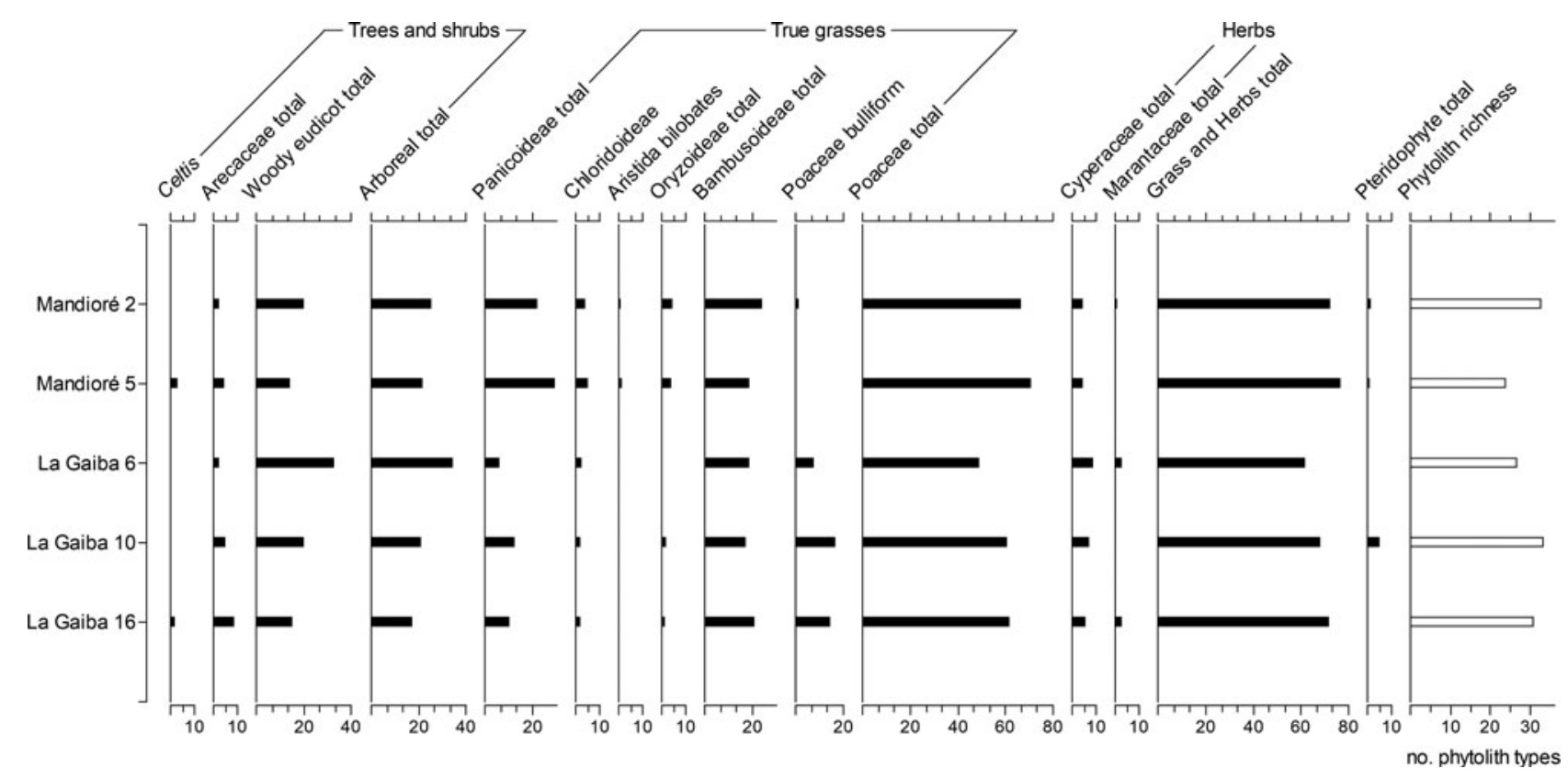

Figure 4. Summary phytolith diagram for two Laguna Mandioré surface samples and three Laguna La Gaiba surface samples. Phytoliths presented as percentage of diagnostic total. 
type and Bambusoideae-type phytoliths are higher in abundance at Mandioré 2, while Panicoideae type and Celtis phytoliths are higher at Mandioré 5. Phytolith richness is higher at Mandioré 5 (33) than at Mandioré 2 (24).

The relative abundance of phytolith types was more variable between Laguna La Gaiba surface samples than between Laguna Mandioré surface samples, with La Gaiba 10 and 16 more similar to each other than to La Gaiba 6. Phytolith richness at La Gaiba 6 (27) is lower than richness at La Gaiba 10 and 16 (34 and 30, respectively). Woody eudicot-type phytoliths are significantly higher in abundance at La Gaiba $6(33 \%$ compared with $15 \%-20 \%$ at La Gaiba 10 and 16), while the total Poaceae phytolith abundance is lower, particularly Panicoideae types (6\% compared with $11 \%-12 \%$ at La Gaiba 10 and 16).

Across all five surface samples from the two lakes, grass and herb phytolith percentages are broadly consistent, including Cyperaceae, Poaceae, and Bambusoideae phytoliths. The major differences between these phytolith samples are the higher arboreal phytolith abundance at La Gaiba 6 and the higher Panicoideae-type phytolith abundance at Mandioré, particularly Mandioré 5.

\section{Palaeo results for Laguna Mandioré 5}

\section{Chronology}

Seven Holocene accelerator mass spectrometry (AMS) ${ }^{14} \mathrm{C}$ dates were obtained from bulk sediment, spaced evenly throughout the Holocene section of the core $(0-360 \mathrm{~cm}$ depth) (Table 1). Because carbonate content (LOI at $950^{\circ}$ C) was below 5\% throughout the core, any "hard-water effect" is likely to be negligible. The relationship between radiocarbon dates and stratigraphic positions was modelled using Bayesian Markov chain Monte Carlo statistical modelling (Blaauw and Christen, 2011) with 73 subdivisions along the sediment core (Fig. 5).

\section{Vegetation, fire, and geochemical proxies}

Four statistically significant pollen zones (PZs 1-4) were identified based on the CONISS analysis (Grimm, 1987) and broken stick model (Bennett, 1996).
PZ1-early Holocene (10,400-7100 cal yr BP). The pollen assemblages in the early Holocene are characterised by fluctuations in pollen of Poaceae $(30 \%-55 \%)$ and Cyperaceae $(20 \%-40 \%)$ and a peak in Alternanthera pollen up to $50 \%$ at $9700 \mathrm{cal} \mathrm{yr} \mathrm{BP} \mathrm{(Fig.} \mathrm{6).} \mathrm{Arecaceae} \mathrm{pollen} \mathrm{is} \mathrm{present}$ at $1 \%-3 \%$ throughout the pollen zone, as is Urticaceae/ Moraceae pollen at $1 \%-7 \%$ (Fig. 6). Other taxa with pollen present at low abundance $(<2 \%)$ throughout this period include Schinopsis, Spondias, Gallesia, Trema, Annonaceae, and Erythroxylum. Pollen of the herbs Amaranthus and Gomphrena appear at low abundance $(<2 \%)$ around 8000 cal yr BP and afterwards towards the top of PZ1. Aquatic pollen increases up to $20 \%$ towards the top of PZ1, driven by increases in Sparganium pollen. The phytolith assemblages from this zone show the Poaceae signal is formed by equal contributions from Bambusoideae and Panicoideae-type phytoliths (Fig. 7).

Most charcoal particles are wood fragments between 100 and $180 \mu \mathrm{m}$ in size, which peak in abundance just after 8000 cal yr BP (Fig. 8). C/N ratios range from 13 to 15 in this pollen zone, while $\delta^{13} \mathrm{C}$ ranges from $-18 \%$ o to $-27 \%$ o (Fig. 9). Rb/K, Fe/K, and $\mathrm{Ca} / \mathrm{Ti}$ are low throughout. The $\%$ $\mathrm{LOI}$ at $550^{\circ} \mathrm{C}, \% \mathrm{C}$, and $\% \mathrm{~N}$ stay low throughout this pollen zone, and the lithology of the core shows the highest clay content of the Holocene (Fig. 9).

PZ2-mid-Holocene phase 1 (7100-6100 cal yr BP). Pollen of Astronium and Anadenanthera trees both reach peak abundance in this period at $9 \%$ and $11 \%$, respectively (Fig. 6). Curatella americana pollen also reaches peak abundance at 5\%. Other arboreal taxa remain at constant levels through this period, including Alchornea, Celtis, and Helicostylis. Spondias, Schinopsis, Mimosa, and Trema pollen are present at low $(<2 \%)$ abundance. Pollen of the herb Alternanthera peaks twice (10\%), and pollen of the aquatic plant Sparganium reaches peak abundance (32\%), while Poaceae pollen declines slightly to $22 \%-30 \%$. Poaceae phytolith abundance and the proportion of Bambusoideae to Panicoideae phytolith types remain constant (Fig. 7). Marantaceae phytoliths are present at low abundance $(<2 \%)$, and Asteraceae platelets are present in the $\mathrm{C}$-fraction (Fig. 7).

Table 1. Radiocarbon dates for Mandioré core 5. The material for all samples was bulk sediment. Dates were calibrated using calibration curve IntCal13 (Reimer et al., 2013) in Bacon 2.3.4 package in R v. 3.4.1 (Blaauw and Christen, 2011).

\begin{tabular}{|c|c|c|c|c|c|c|c|}
\hline $\begin{array}{l}\text { Publication } \\
\text { code }\end{array}$ & $\begin{array}{l}\text { Sample } \\
\text { identifier }\end{array}$ & $\begin{array}{l}\text { Stratigraphic } \\
\text { position }(\mathrm{cm})\end{array}$ & $\begin{array}{c}{ }^{14} \mathrm{C} \text { enrichment } \\
(\% \text { modern })\end{array}$ & $\begin{array}{c}\text { Conventional }{ }^{14} \mathrm{C} \text { age } \\
(\mathrm{yr} \mathrm{BP} \pm 1 \sigma)\end{array}$ & $\begin{array}{c}\text { Carbon } \\
\text { content }(\% \mathrm{wt}) \\
\end{array}$ & $\begin{array}{c}\delta^{13} \mathrm{C} \\
(\% o) \\
\end{array}$ & $\begin{array}{c}\text { Calibrated age } \\
\text { range }(y r B P \pm 2 \sigma)\end{array}$ \\
\hline SUERC-72913 & Mand-50 & $50-51$ & 79.36 & $1857 \pm 37$ & 6.2 & -20.1 & $1633-1933$ \\
\hline SUERC-72914 & Mand-100 & $100-100.5$ & 61.97 & $3843 \pm 37$ & 5.5 & -19.3 & 3999-4416 \\
\hline Beta - 438857 & 143 & $143-144$ & & $4580 \pm 30$ & & -16.7 & $5037-5461$ \\
\hline SUERC-72915 & Mand-200 & $200-200.5$ & 50.76 & $5448 \pm 38$ & 16.5 & -16.6 & $6114-6429$ \\
\hline Beta - 438858 & 237 & $237-238$ & & $6150 \pm 30$ & & -19.9 & $6850-7178$ \\
\hline SUERC-72916 & Mand-280 & $280-280.5$ & 44.53 & $6499 \pm 38$ & 5.8 & -18.9 & 7376-7913 \\
\hline SUERC-72917 & Mand-360 & $360-360.5$ & 29.26 & $9872 \pm 41$ & 0.9 & -19.9 & $9221-11,446$ \\
\hline
\end{tabular}



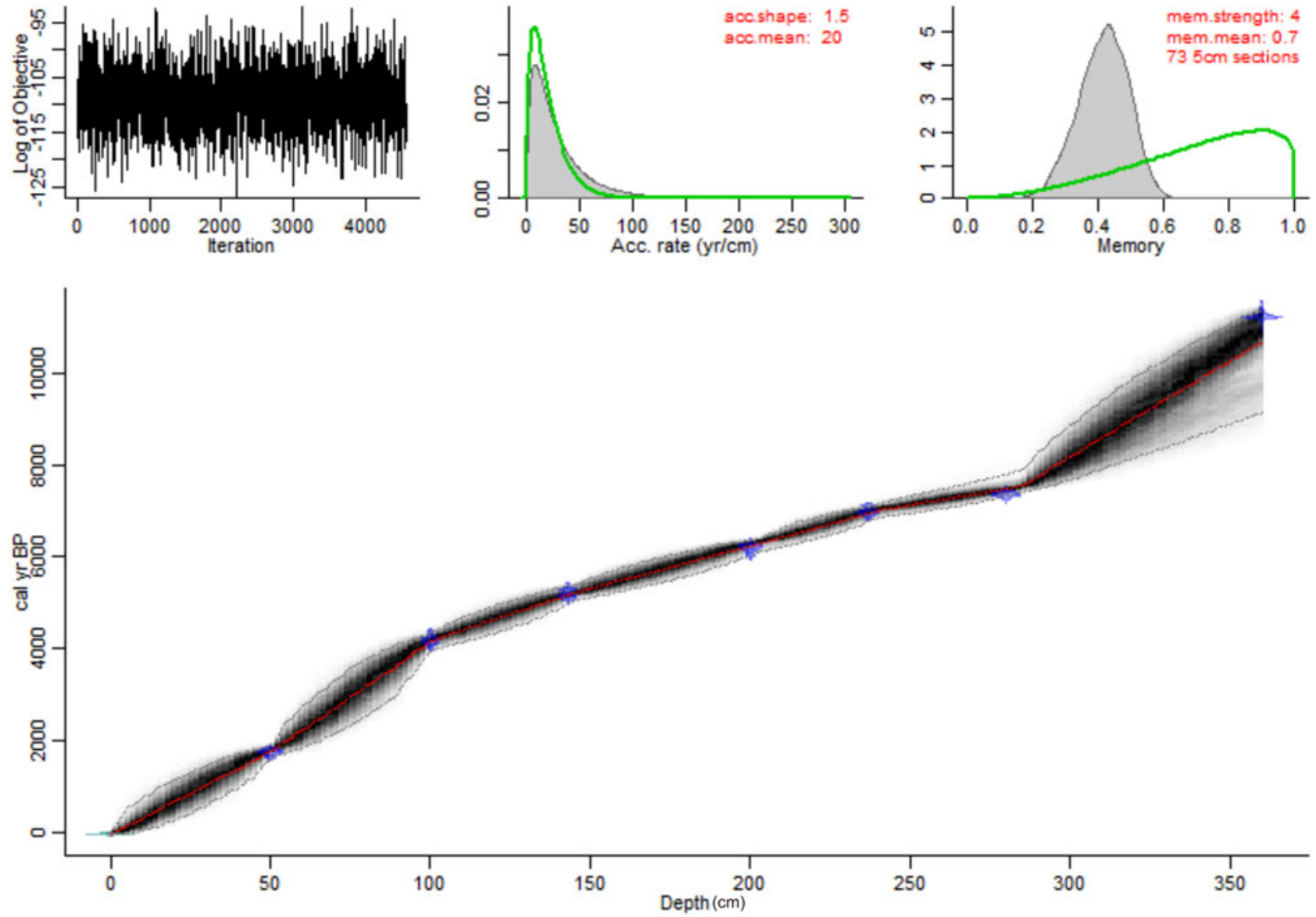

Figure 5. (color online) Age-depth model for Mandioré core 5 built using Bacon 2.3.4 in R 3.4.1 (Blaauw and Christen, 2011). Age is plotted as calibrated years before present (cal yr BP) against depth as centimeters below the sediment-water interface. Accumulation rate is abbreviated to 'acc.', memory is abbreviated to 'mem.'.

Total charcoal concentration fluctuates between 133 and 181 particles/ml wet sediment and continues to be dominated by the $100-180 \mu \mathrm{m}$ woody pieces (Fig. 8). The $\% \mathrm{C}$ and $\% \mathrm{~N}$ peak during PZ2 at $17 \%$ and $1.2 \%$, respectively, while overall the $\mathrm{C} / \mathrm{N}$ ratio increases, ranging from 12 to 17 (Fig. 9). $\delta^{13} \mathrm{C}$ also increases during this period, up to $-16 \%$ o towards the top of the zone. The $\% \mathrm{LOI}$ at $550^{\circ} \mathrm{C}$ increases up to $30 \%$ during PZ2 (Fig. 9). Higher organic content coincides with an increase in $\mathrm{Ca} / \mathrm{Ti}$ compared with PZ1 (Fig. 9).

PZ3-mid-Holocene phase 2 (6100-3600 cal yr BP). Pollen from Astronium, Anadenanthera, and Curatella americana declines towards $4000 \mathrm{cal}$ yr BP at the top of PZ3. Dalbergia/Machaerium and Cedrela pollen abundance peaks around $5000 \mathrm{cal}$ yr BP, while total Moraceae/Urticaceae pollen remains reasonably constant throughout. Acacia, Gallesia, Trema, and Erythroxlyum pollen appears at low $(<2 \%)$ abundance, particularly between 6000 and $5000 \mathrm{cal}$ yr BP. Pollen of the herb Amaranthus also appears at low abundance several times through this pollen zone, while Sparganium pollen abundance declines throughout this period and is superseded by pollen of another aquatic plant, Eichhornia. Poaceae pollen increases towards the top of
PZ3, with a slight increase in the proportion of Bambusoideae phytoliths to Panicoideae phytoliths, although there is no change in the overall Poaceae phytolith abundance (Fig. 7). Heliconiaceae phytoliths are present at low abundance $(<2 \%)$ at $5500 \mathrm{cal}$ yr BP (Fig. 7).

The charcoal record continues to be dominated by the 100 $180 \mu \mathrm{m}$ woody pieces, with a slight increase in $>180 \mu \mathrm{m}$ woody pieces during this period. Total charcoal concentration fluctuates between 87 to 197 particles/ml wet sediment (Fig. 8). The $\% \mathrm{C}$ and $\% \mathrm{~N}$ both decrease through PZ3, with a decrease in overall $\mathrm{C} / \mathrm{N}$ ratios to around 12-14 (Fig. 9). $\delta^{13} \mathrm{C}$ also decreases through this period, from $-17 \%$ at $6100 \mathrm{cal} \mathrm{yr} \mathrm{BP}$ to $-27 \%$ at $3800 \mathrm{cal} \mathrm{yr} \mathrm{BP}$. Ca/Ti peaks around $6000 \mathrm{cal} \mathrm{yr} \mathrm{BP}$, at peak mid-Holocene drought, and then declines towards the top of $\mathrm{PZ} 3 . \mathrm{Rb} / \mathrm{K}$ and $\mathrm{Fe} / \mathrm{K}$ increase from 4000 cal yr BP (Fig. 9).

PZ4-late Holocene (3600 cal yr BP to present). Astronium and Anadenanthera pollen maintain a continuous presence but at lower abundances, reaching maximum levels for this pollen zone of $3 \%$ and $5 \%$, respectively, in the present (Fig. 6). Curatella americana also declines in abundance to $0.6 \%$ at the modern day. Pollen of Alchornea, Celtis, and 

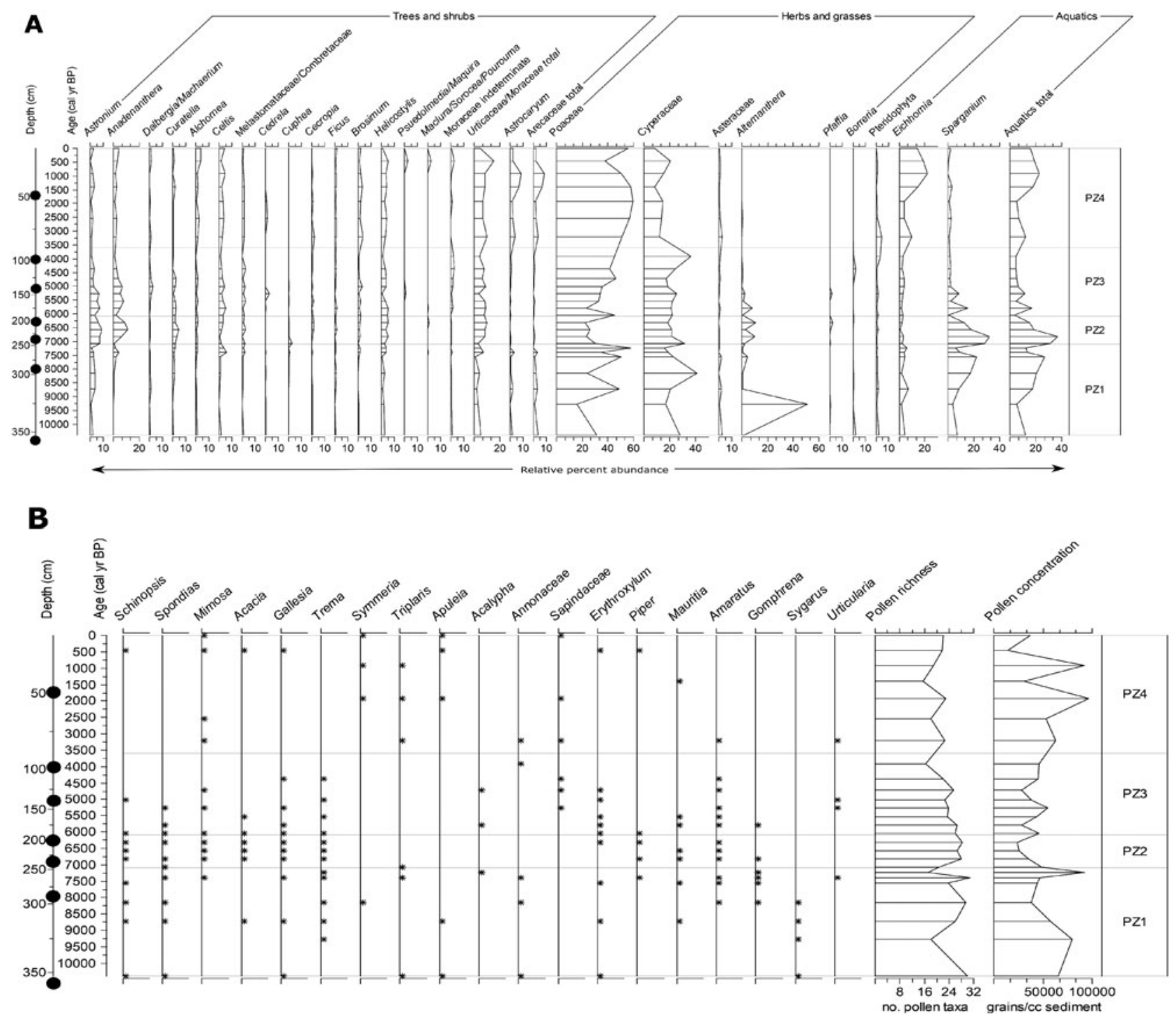

Figure 6. Pollen plotted against age of sediment in calibrated years before present (cal yr BP) for Mandioré core 5, with pollen zones marked by grey horizontal lines $(\mathrm{PZ}=$ pollen zone $)$ and dating horizons marked by black circles on secondary depth axis. Pollen presented as percentage of terrestrial sum. (A) Taxa greater than $2 \%$ abundance in more than 1 sample, displayed as percent abundance of terrestrial total. (B) Taxa with less than $2 \%$ abundance, marked by an asterisk (*), with pollen richness and pollen concentration.

Helicostylis maintains constant abundance throughout PZ4. Pollen from the palm Astrocaryum peaks around 1000 cal yr BP, as does pollen from the deep-water aquatic Eichhornia. Symmeria paniculata pollen is present at low abundance throughout PZ4 (Fig. 6). Phytoliths are found from Strelitziaceae, which includes the genera Phenakospermum, and from Heliconiacaeae, Marantacaeae, and Asteraceae (Fig. 7).

There is a peak in total charcoal concentration at $2000 \mathrm{cal}$ yr BP up to 280 particles/ml wet sediment, set against fluctuations from 71 to 212 particles/ml (Fig. 8). The charcoal record continues to be dominated by woody pieces between $100-180 \mu \mathrm{m}$ with a small peak in woody pieces $>180 \mu \mathrm{m}$ around 2400 cal yr BP (Fig. 8). C/N ratios decline further throughout the late Holocene, from 13 to 9 in the present, with an increase in both $\% \mathrm{C}$ and $\% \mathrm{~N}$ up to $6.2 \%$ and $0.8 \%$ in the present (Fig. 9). $\mathrm{Rb} / \mathrm{K}$ and $\mathrm{Fe} / \mathrm{K}$ are high during PZ4
(Fig. 9). $\delta^{13} \mathrm{C}$ also decreases slightly compared with PZ3 and fluctuates between $-22 \%$ and $-32 \%$ (Fig. 9).

\section{DISCUSSION}

\section{Implications of modern pollen and phytolith data for interpretation of fossil data from Lagunas Mandioré and La Gaiba}

Modern pollen and phytolith assemblages from Laguna La Gaiba confirm that the Pantanal wetlands do have an influence on the palaeo-vegetation records, particularly in the north basin (La Gaiba 16), which merges into the Pantanal wetlands (Fig. 2), where the only arboreal pollen taxa are Alchornea, which includes flood-tolerant tree species 


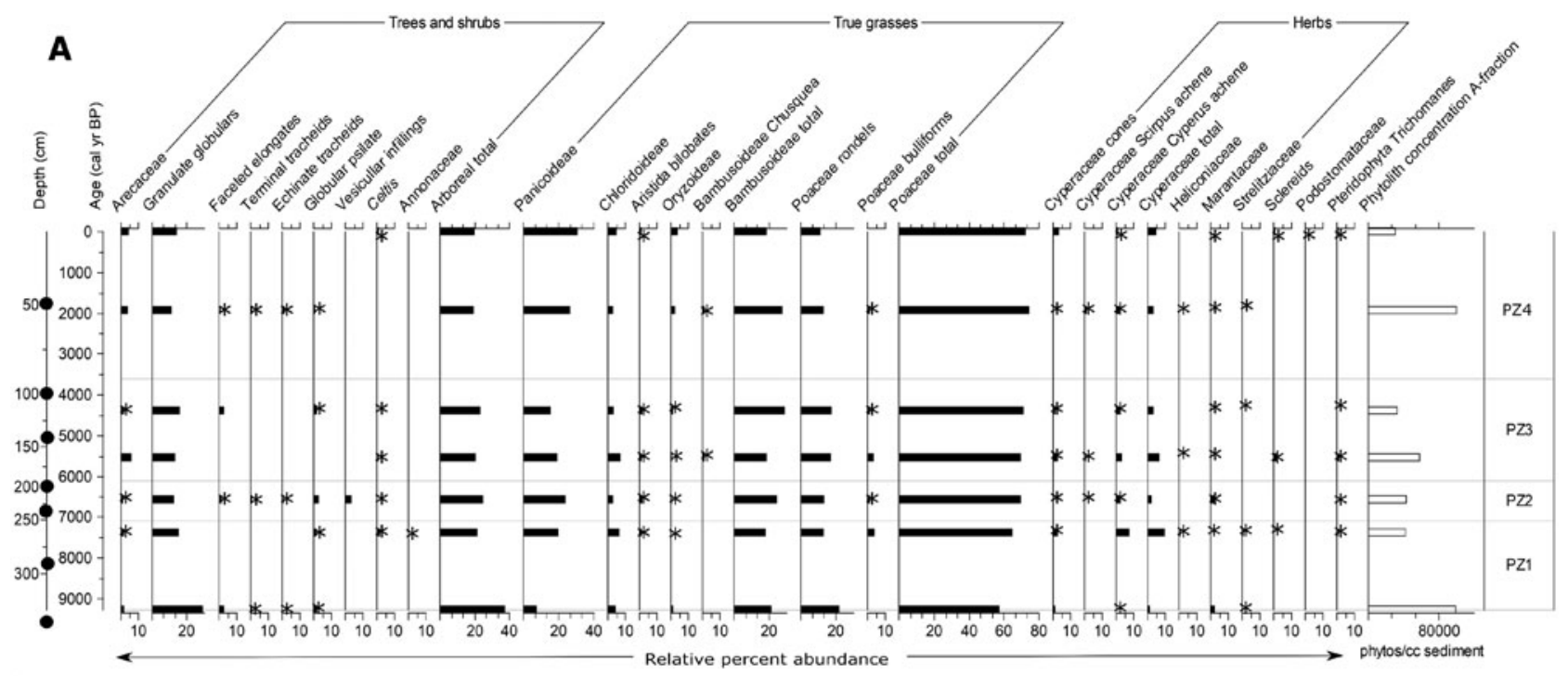

B

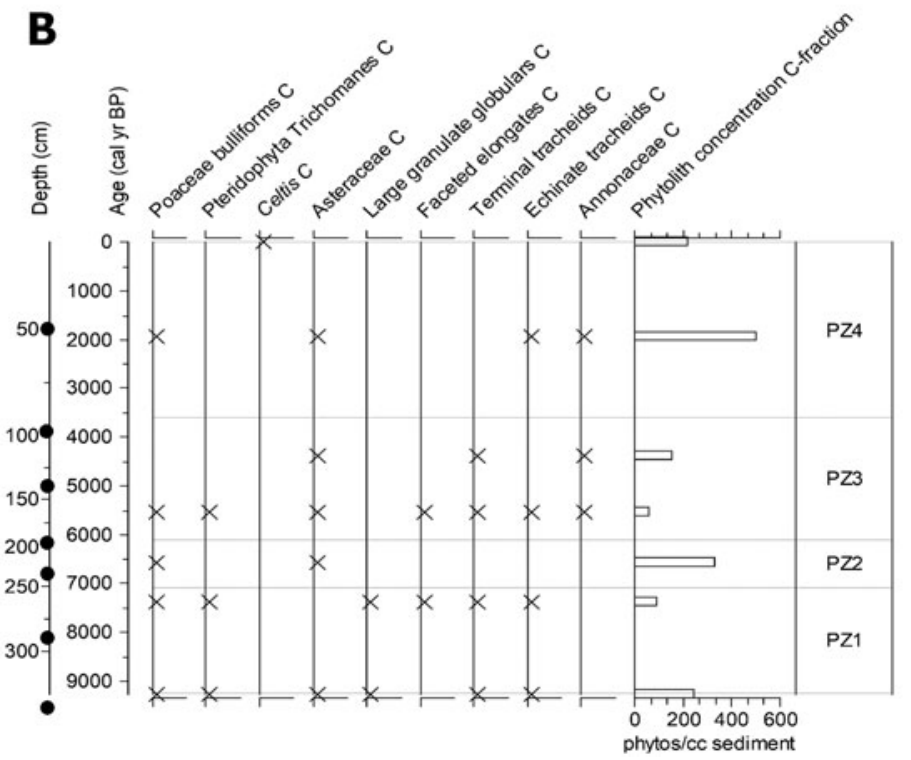

Figure 7. Phytoliths plotted against age of sediment in calibrated years before present (cal yr BP) for Mandioré core 5, with pollen zones marked by grey horizontal lines $(\mathrm{PZ}=$ pollen zone) and dating horizons marked by black circles on secondary depth axis. (A) A-Fraction taxa, with taxa with less than $2 \%$ abundance marked by an asterisk (*). (B) C-Fraction taxa, presence shown by "X".

(Nunes da Cunha et al., 2007), and Anadenanthera (Fig. 3). The southern end of the south basin is surrounded by dry forest with a small palm swamp, which is reflected in the abundance of pollen from key dry forest taxa Astronium and Anadenanthera (Gosling et al., 2009) and greater abundance of phytoliths from arboreal plants at La Gaiba 6 . This is $\sim 3$ $\mathrm{km}$ west of the long-core site that Whitney et al. (2011, 2013) used for the vegetation reconstruction of the past $45,000 \mathrm{yr}$ of Chiquitano semideciduous dry forest. The phytolith assemblages presented here confirm that this long-core site is likely to be the most representative of the semideciduous dry forest and least influenced by the vegetation of the Pantanal wetlands.

Surface pollen assemblages from Laguna Mandioré contain key dry forest taxa Astronium and Anadenanthera
(Gosling et al., 2009). Although Bambusoideae phytoliths, indicative of semideciduous dry forest (Dickau et al., 2013), are high across all surface samples, Laguna Mandioré samples show a higher total Poaceae abundance than Laguna La Gaiba samples, particularly of Panicoideae types (Fig. 4). As phytoliths from lakes primarily represent local vegetation (Piperno, 2006), the majority of the Panicoideae inputs are likely to reflect local shoreline vegetation at both Mandioré sites ( 2 and 5). However, a minor component of the Panicoideae phytolith signal could be representing extra-local inputs. As the Panicoideae grass subfamily includes both wetland and upland species, this signal could be reflecting influence from the Pantanal wetlands and the upland savannahs of the Amolar hills. The southeast Laguna Mandioré basin is connected to the Pantanal wetlands via a channel to the Paraguay 


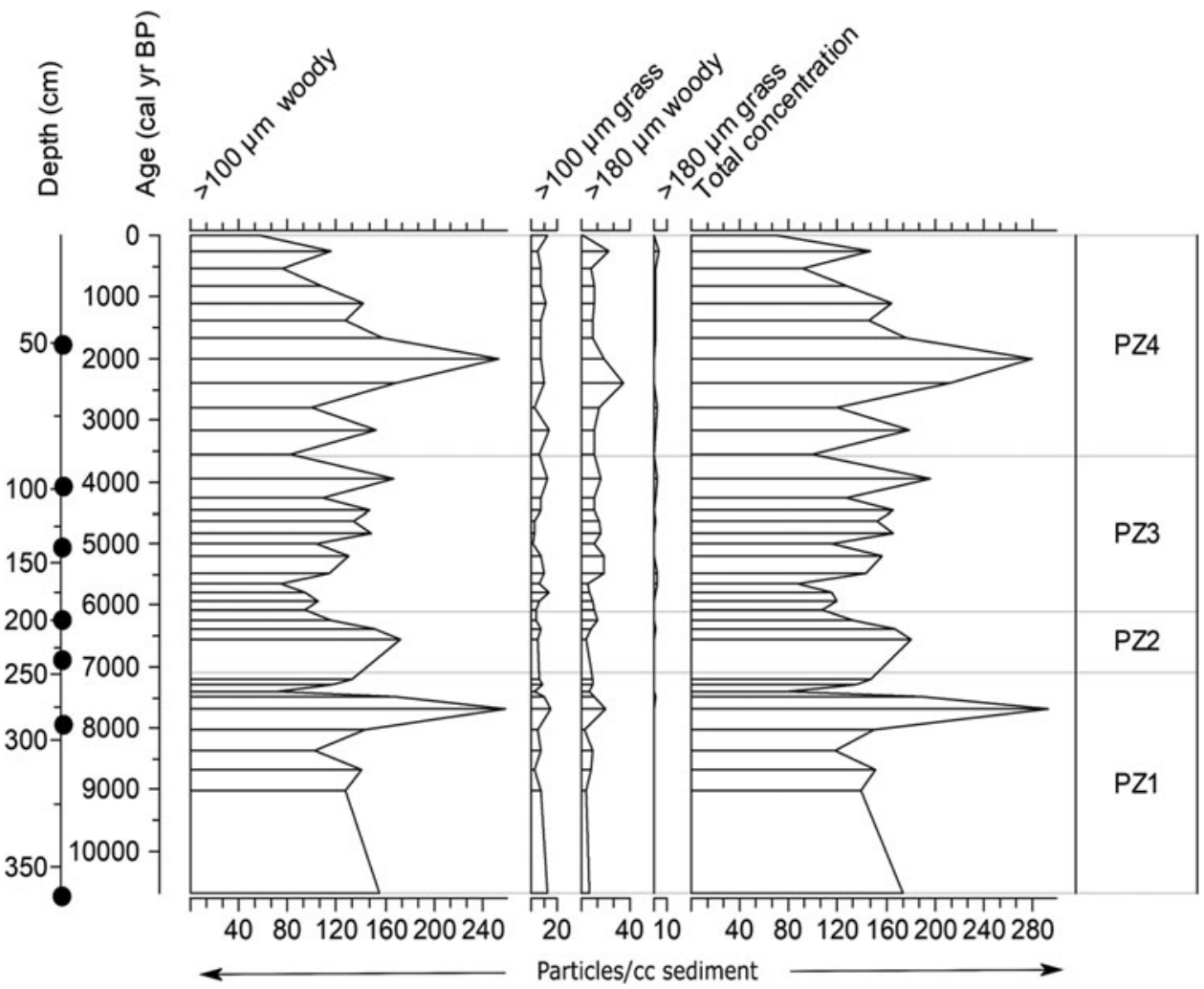

Figure 8. Charcoal concentration plotted against age of sediment in calibrated years before present (cal yr BP) for Mandioré core 5, with pollen zones marked by grey horizontal lines $(\mathrm{PZ}=$ pollen zone) and dating horizons marked by black circles on secondary depth axis. Charcoal separated into $>100 \mu \mathrm{m}$ and $>180 \mu \mathrm{m}$ size fractions and classified as being from woody or grass plant material origin. Charcoal counts displayed as number of particles per cubic centimetre of wet sediment.

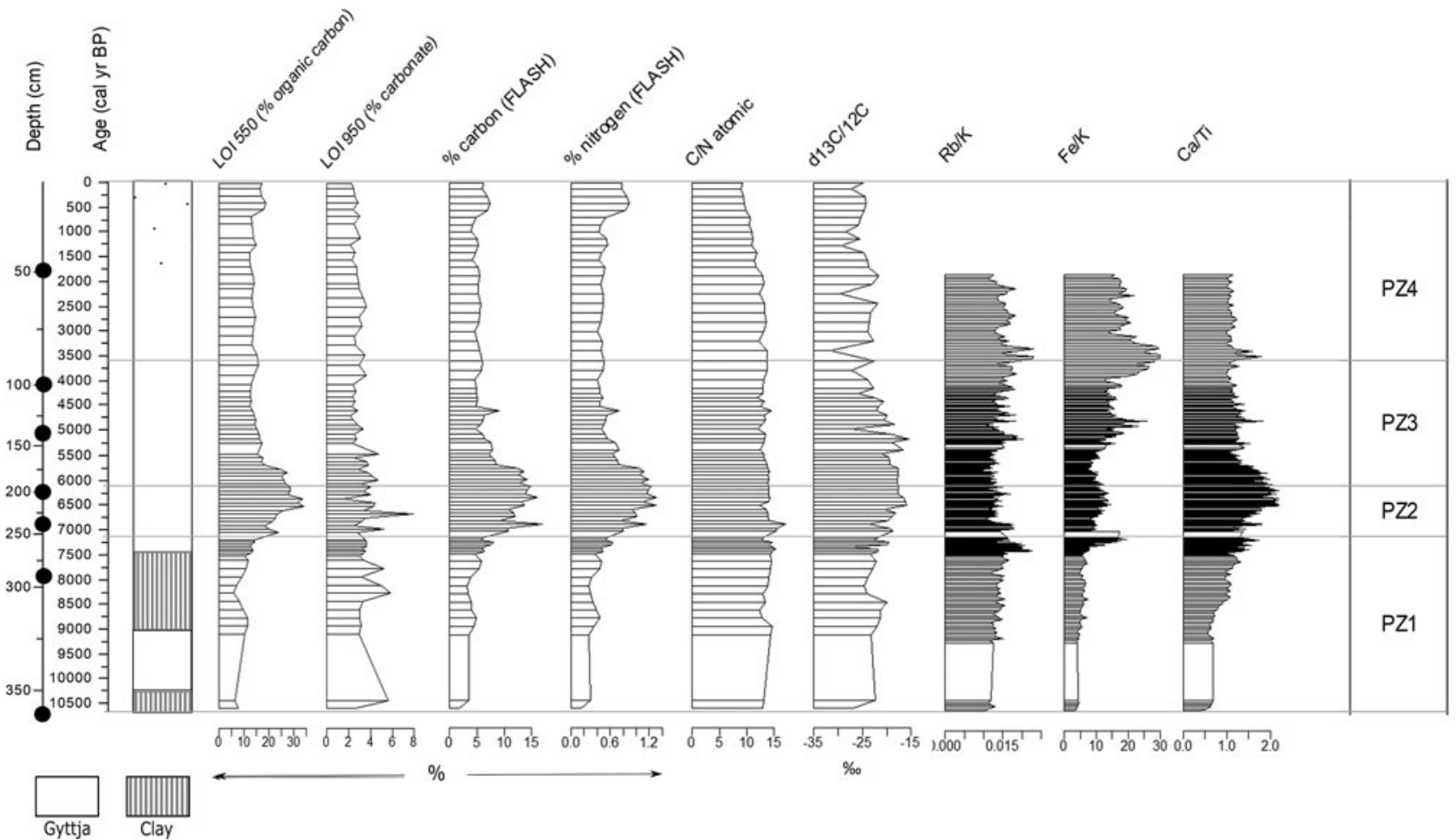

Figure 9. Geochemical proxies and lithology column plotted against calibrated years before present (cal yr BP) for Mandioré core 5, with pollen zones marked by grey horizontal lines $(\mathrm{PZ}=$ pollen zone) and dating horizons marked by black circles on secondary depth axis. $\%$ LOI at $550{ }^{\circ} \mathrm{C}, \% \mathrm{LOI}$ at $950{ }^{\circ} \mathrm{C}, \% \mathrm{C}$, and $\% \mathrm{~N}$ are presented as percentages. $\delta^{13} \mathrm{C} /{ }^{12} \mathrm{C}$ is presented as per mille (\%o) deviation from VPDB standard. Atomic $\mathrm{C} / \mathrm{N}$ is presented as a ratio. XRF results are presented as ratios. 
River that is surrounded by wetlands (McGlue et al., 2012), which may wash pollen, phytoliths, and other materials into the south basin during the wet season. As Mandiore 2 is situated in the southern Laguna Mandioré basin, Pantanal wetland grasses are more likely to have contributed to the high Panicoid phytolith abundance at this site. Mandiore 5 is in the northern basin, just $\sim 2 \mathrm{~km}$ from the base of the Amolar hills, and it is therefore more likely that contributions to the Panicoid abundance at this site are from the upland savannah atop the Amolar hills rather than the Pantanal wetlands.

The surface pollen assemblage from Mandioré 5 contains Curatella americana pollen at $\sim 1 \%$, which is comparable to abundances found in pollen traps from within terra firme (cerrado) upland savannah at Noel Kempff Mercado National Park (Jones et al., 2011). Low pollen abundance in palaeo-records is expected for Curatella americana and other savannah tree pollen, such as Brysonima or savannah shrubs such as Schefflera or Alibertia, due to their entomophilous pollination mechanism (Jones et al., 2011; Hilje et al., 2015). The low abundance or absence of these key savannah pollen tree taxa in the present is therefore unsurprising despite the close proximity of Mandiore 5 to the Amolar hills upland savannah. Any increase in the abundance of pollen from these savannah taxa in the fossil record would suggest an increase in upland savannah extent (i.e., downslope expansion) compared with the present day.

\section{Holocene vegetation reconstruction at Laguna Mandioré 5}

\section{PZ1-early Holocene $(10,400-7100$ cal yr BP)}

This pollen zone is suggestive of a semideciduous dry forest community occupying the hillslopes around Laguna Mandioré in the early Holocene, with a significant herbaceous component. Key dry forest taxa such as Anadenanthera (3\%) and Astronium (4\%) are present (Gosling et al., 2009; Fig. 6). The abundance of Urticaceae/Moracaceae pollen in this zone at $1 \%-7 \%$ is well below the $40 \%$ level expected for closed-canopy humid evergreen forest (Gosling et al., 2009). The most abundant Moraceae genus in the assemblage is Helicostylis, which has moisture-dependent species in evergreen and liana forests (Burn and Mayle, 2008), and therefore probably represents gallery and riparian evergreen forest along lakeshores and rivers around Laguna Mandioré. Pollen of other arboreal taxa present throughout this period include Schinopsis, Spondias, Gallesia, Trema, Annonaceae, and Erythroxylum, suggesting the presence of a closedcanopy forest. The herbaceous component of the vegetation is characterised by fluctuation in Poaceae and Alternanthera pollen (Fig. 6). Phytolith assemblages show that the Poaceae signal is characterised by equal contributions from Bambusoideae- and Panicoideae-type phytoliths (Fig. 7). High Bambusoideae phytolith abundance is indicative of understorey bamboo in semideciduous dry forest (Dickau et al., 2013), whereas Panicoideae phytoliths are generally indicative of open-savannah habitats, either wetland or upland (Piperno, 2006; Dickau et al., 2013). The phytolith assemblage therefore confirms the presence of semideciduous dry forest local to the site during this period, while also suggesting some local savannah inputs. As phytoliths primarily represent local vegetation (Piperno, 2006), these Panicoideae phytolith inputs therefore most likely reflect predominantly local shoreline vegetation, with only minor inputs from the upland savannah atop the Amolar hills, which at present is $\sim 2 \mathrm{~km}$ from the lakeshore.

$\mathrm{C} / \mathrm{N}$ ratios (13-15) in this pollen zone indicate a mixture of algal and terrestrial inputs to the lake sediment (Fig. 8). The $\mathrm{C} /$ $\mathrm{N}$ ratio of algal material typically ranges from 4 to 10 , whereas $\mathrm{C}_{3}$ terrestrial material has a $\mathrm{C} / \mathrm{N}$ ratio $>20$ (Meyers and Teranes, 2001). The $\mathrm{C} / \mathrm{N}$ ratios from this pollen zone are therefore suggestive of high algal productivity in the lake, with terrestrial inputs. $\delta^{13} \mathrm{C}$ values indicate mixed $\mathrm{C}_{3} / \mathrm{C}_{4}$ vegetation inputs $\left(\mathrm{C}_{3}\right.$ vegetation range is $-20 \%$ o to $-35 \%$ o, compared with $-9 \%$ to $-16 \%$ for $\mathrm{C}_{4}$ vegetation) (Boutton, 1996).

\section{PZ2-mid-Holocene phase 1 (7100-6100 cal yr BP)}

Astronium and Anadenanthera, two key pollen taxa indicative of semideciduous dry forest (Gosling et al., 2009), both reach peak abundance in this period at $9 \%$ and $11 \%$, respectively (Fig. 5). Curatella americana, a savannah tree, also reaches peak abundance at $5 \%$, much higher than the $\sim 1 \%$ abundance found in pollen traps within upland savannah at Noel Kempff Mercado National Park (Jones et al., 2011).This combination of pollen taxa shows that the lake record is detecting the presence of the dry forest-upland savannah ecotone on the Amolar hills for the first time in the Holocene. This finding suggests that the area of upland savannah within the lake catchment has increased, likely due to a shift in the dry forest-upland savannah ecotone downslope from the neighbouring Amolar hills. The continued presence of closed-canopy forest in the catchment is demonstrated by the constant levels of pollen from other arboreal taxa such as Alchornea, Celtis, and Helicostylis. Poaceae pollen abundance declines slightly within this pollen zone (Fig. 6), while the phytolith assemblage shows a constant proportion of Bambusoideae to Panicoideae types (Fig. 7). This phytolith assemblage indicates a constant proportion of dry forest (Bamusoideae) and savannah (Panicoideae) inputs from the vegetation close to the shore, suggesting that savannah encroachment did not reach the dry forest vegetation at the base of the Amolar hills.

$\mathrm{C} / \mathrm{N}$ ratios increase in PZ2 (12-17), suggesting greater terrestrial inputs to the lake sediment during this period compared with PZ1 (Fig. 9). $\delta^{13} \mathrm{C}$ also increases during this period, up to $-16 \%$ o towards the top of the zone. Together, the shifts in $\mathrm{C} / \mathrm{N}$ and $\delta^{13} \mathrm{C}$ indicate greater terrestrial $\mathrm{C}_{4}$ vegetation inputs compared with PZ1, supporting the interpretation of $\mathrm{C}_{4}$ upland savannah expansion on the slopes of the Amolar hills. Organic content of the sediment increases during PZ2 with $\% \mathrm{LOI}$ at $550^{\circ} \mathrm{C}$ increasing up to $30 \%$, coinciding with an increase in the $\mathrm{Ca} / \mathrm{Ti}$ ratio (Fig. 9), suggesting evaporative concentration of the lake waters (Metcalfe 
et al., 2014), possibly due to the reduction in precipitation during the mid-Holocene drier period. This interpretation is supported by peak abundance (32\%) of pollen of the aquatic plant Sparganium, a genus of floating or emergent aquatic marsh plants (Ricketson, 2001), reflecting an increase in aquatic vegetation of shallow lake waters.

\section{PZ3-mid-Holocene phase 2(6100-3600 cal yr BP)}

Pollen from key dry forest taxa Astronium and Anadenanthera and from the savannah tree Curatella americana decline towards $4000 \mathrm{cal} \mathrm{yr} \mathrm{BP}$ at the top of PZ3, indicating a reduction in the extent of upland savannah and a shift of the dry forest-upland savannah ecotone upslope to its early Holocene position. Closed-canopy forest is maintained in the catchment, as demonstrated by pollen of Dalbergial Machaerium, Cedrela, Acacia, Gallesia, Trema, and Erythroxlyum. Poaceae pollen increases towards the top of PZ3, with a slight increase in the proportion of Bambusoideae phytoliths to Panicoideae phytoliths, suggesting a slight increase in dry forest vegetation close to the shoreline (Fig. 6).

$\mathrm{C} / \mathrm{N}$ ratios decrease slightly during this period, suggesting a slight reduction in terrestrial inputs compared with PZ2 (Fig. 8). $\delta^{13} \mathrm{C}$ also decreases through this period, from $-17 \%$ o to $-27 \%$ o, demonstrating a return to predominantly $\mathrm{C}_{3}$ vegetation inputs from a mix of terrestrial and aquatic sources. The return to a $\mathrm{C}_{3}$-dominated signal suggests a reduction in $\mathrm{C}_{4}$ upland savannah vegetation reflecting the reduction in savannah on the slopes of the Amolar hills as the dry forest-upland savannah ecotone shifts upslope. $\mathrm{Ca} / \mathrm{Ti}$ peaks around $6000 \mathrm{cal} \mathrm{yr} \mathrm{BP}$, at peak mid-Holocene drought, and then declines towards the top of PZ3, suggesting peak evaporative concentration of lake waters at $6000 \mathrm{cal} \mathrm{yr}$ BP (Metcalfe et al., 2014). From $4000 \mathrm{cal} \mathrm{yr} \mathrm{BP} \mathrm{Rb/K}$ and $\mathrm{Fe} / \mathrm{K}$ increase, suggesting an increase in transport of weathered material to the lake, which could indicate an increase in precipitation (McGlue et al., 2012; Metcalfe et al., 2014). Sparganium pollen abundance declines throughout this period and is superseded by an aquatic plant typical of deeper waters, Eichhornia (Hamilton, 2002), supporting the interpretation of an increase in lake levels.

\section{PZ4-late Holocene (3600 cal yr BP-present)}

Pollen of key dry forest taxa Astronium and Anadenanthera maintain a continuous presence up to the modern day but at lower abundances compared with the mid-Holocene, while Curatella americana pollen declines towards the present (Fig. 6), reflecting the reduced extent of upland savannah and upslope shift of the dry forest-upland savannah ecotone to its present position on the slopes of the Amolar hills. Alchornea, Celtis, and Helicostylis all maintain constant abundance throughout PZ4, reflecting the persistence of closed-canopy forest.

There are several indicators in the vegetation that precipitation is increasing during PZ4, including the presence of pollen from inundation-tolerant tree Symmeria paniculata and peak abundance of the deep-water aquatic Eichhornia (Fig. 6). Additionally, phytoliths are found from Strelitziaceae, which includes the genera Phenakospermum, a tree common in inundated, wet environments as well as Heliconiacaeae, Marantacaeae, and Asteraceae phytoliths, which can be indicators of inundated shoreline or savannah vegetation (Dickau et al., 2013; Fig. 7).

$\mathrm{C} / \mathrm{N}$ ratios decline further throughout the late Holocene (Fig. 9) suggesting higher algal productivity towards the present, possibly due to increasing precipitation in the late Holocene and hence greater weathering of soils and nutrient inwash to the lake. This interpretation is supported by high $\mathrm{Rb} / \mathrm{K}$ and $\mathrm{Fe} / \mathrm{K}$ ratios, which have been interpreted to show an increase in transport of weathered material to lakes in this region of the Pantanal (McGlue et al., 2012; Metcalfe et al., 2014) (Fig. 9). $\delta^{13} \mathrm{C}$ also decreases slightly compared with $\mathrm{PZ3}$ and fluctuates within the $\mathrm{C}_{3}$ vegetation range (Boutton, 1996), reflecting the dominance of $C_{3}$ forest vegetation over $\mathrm{C}_{4}$ upland savannah vegetation in the lake catchment in the present.

\section{Impact of drier mid-Holocene climate}

\section{Dry forest biome and floristics}

Key dry forest taxa in the pollen record-Anadenanthera and Astronium - reach peak abundance between 7000 and 6000 cal yr BP and maintain high abundance until $\sim 4000 \mathrm{cal} \mathrm{yr}$ BP (Fig. 10). This fits with the timing of the mid-Holocene drier climatic period in Andean palaeoclimate records such as Laguna Titicaca (Baker et al., 2001) and Laguna Pumachoca (Bird et al., 2011) as well as lowland Pantanal records such as Jaraguá Cave (Novello et al., 2017), Laguna Negra (Rasbold et al., 2019), and Laguna La Gaiba (Whitney et al., 2011, 2014; McGlue et al., 2012; Whitney and Mayle, 2012; Metcalfe et al., 2014; Fornace et al., 2016; Fig. 11). Additionally, peak $\mathrm{Ca} / \mathrm{Ti}$ and low $\mathrm{Rb} / \mathrm{K}$ and $\mathrm{Fe} / \mathrm{K}$ around $6000 \mathrm{cal} \mathrm{yr} \mathrm{BP}$ at Laguna Mandioré suggest reduced mineral wash into the lake and support the identification of a mid-Holocene drier climate between 7000 and 4000 cal yr BP (Fig. 9). These findings are consistent with peak $\mathrm{Ca} / \mathrm{Ti}$ at Laguna La Gaiba from 9000 to 4000 cal yr BP (Metcalfe et al., 2014), demonstrating regionally consistent geochemical changes.

Alongside increases in Astronium and Anadenanthera, other forest pollen taxa such as Helicostylis, Melastomataceae/Combretaceae, Alchornea, and Celtis remain present and do not change in abundance through the mid-Holocene drier period (Fig. 6). These findings support the hypothesis that closed-canopy dry forest is maintained throughout the mid-Holocene drier period but that floristic changes do occur, with an increase in typical dry forest taxa that are more resilient to water stress (Reich and Borchert, 1984; Nunes da Cunha et al., 2007) and hence outcompete more moisture-dependent taxa. The high abundance of Bamusoideae phytoliths, typical of dry forest (Dickau et al., 2013), at key horizons in the pollen record further supports the 


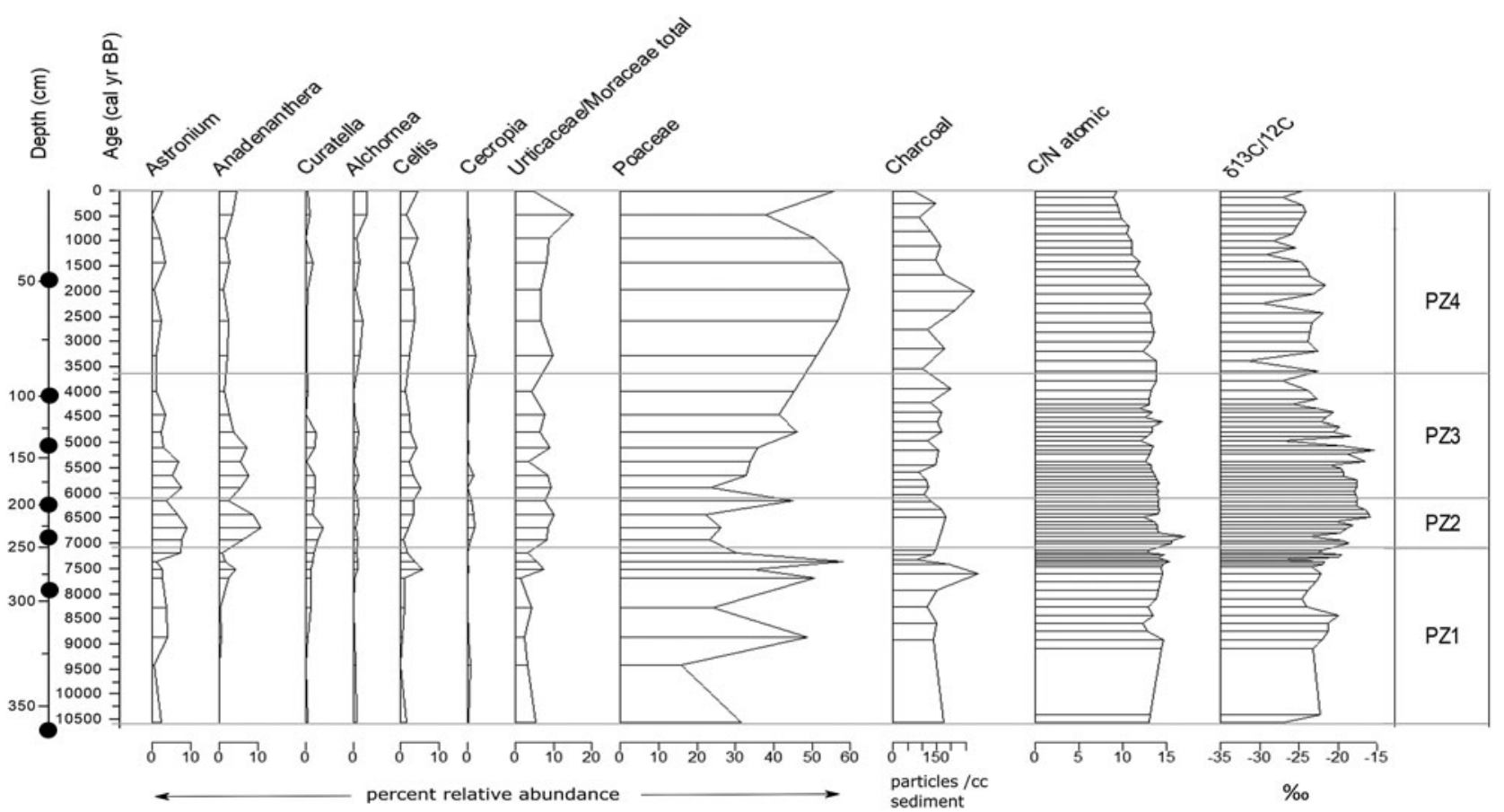

Figure 10. Summary vegetation diagram for Mandioré core 5 plotted against calibrated years before present (cal yr BP) with pollen zones marked by grey horizontal lines $(\mathrm{PZ}=$ pollen zone) and dating horizons marked by black circles on secondary depth axis. Key pollen taxa presented as percentage of terrestrial total, total charcoal concentration presented as particles per cubic centimetre of wet sediment, $\delta^{13} \mathrm{C} /{ }^{12} \mathrm{C}$ presented as per mille $(\%)$, and $\mathrm{C} / \mathrm{N}$ presented as a ratio.

interpretation that closed-canopy forest was maintained throughout the Holocene (Fig. 7). This combination of pollen and phytolith analyses strengthens the findings of Whitney et al. (2014) who first identified this dry forest response at Laguna La Gaiba with increases in Astronium and
Anadenanthera pollen up to $8 \%$ and $13 \%$, respectively, during the mid-Holocene but found no evidence of opening up of the forest canopy. Despite these floristic changes, palynological richness does not decrease during the mid-Holocene drier period at Laguna Mandioré but remains constant throughout

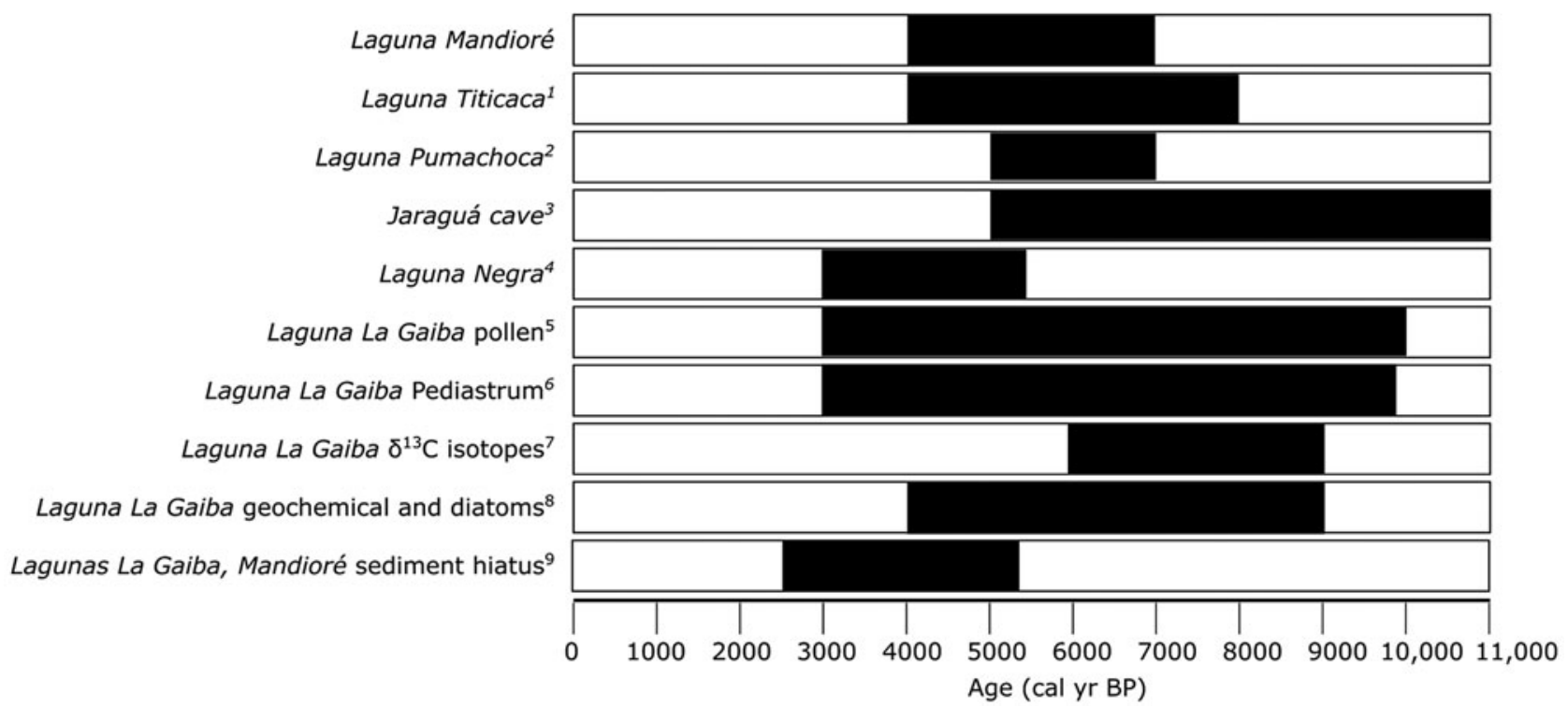

Figure 11. Schematic diagram summarising key records of the mid-Holocene drier climatic period in the Andes (Lagunas Titicaca and Pumachoca) and Pantanal lowlands (Jaraguá Cave, Lagunas Negra, and La Gaiba) for comparison with Laguna Mandioré. Four studies have been conducted at Laguna La Gaiba; here they are differentiated by the main palaeo data set used. Time is presented on the x-axis as calibrated years BP (cal yr BP). Black bars represent period of drier climatic conditions interpreted by the authors of the relevant palaeo record (reference to original publication). 
the Holocene (Fig. 6). This finding contrasts with the dry forest record from Laguna La Gaiba, where palynological richness was low from 10,000 to 3000 cal yr BP during the period of drier climatic conditions and increased from 3000 cal yr BP to the present (Whitney et al., 2014). As the Laguna Mandioré record reflects a mixture of dry forest and upland savannah, particularly during the mid-Holocene, the potential loss of diversity in the dry forest may be compensated for by the addition of upland savannah taxa.

This record shows no clear relationship between changes in fire regime and changes in floristic composition in the forest, thus supporting our hypothesis that climate, rather than fire, is the primary control upon floristic composition of the dry forest. Charcoal concentration does not increase during the mid-Holocene drier period, except for a peak near $8000 \mathrm{cal}$ yr BP (Fig. 10). This coincides with the early phase of the mid-Holocene drier period in this region and could represent an intrusion of fire from nearby upland savannah on the Amolar hills. Otherwise, charcoal concentration remains constant throughout the Holocene, strengthening the inference from the nearby Laguna La Gaiba charcoal record (Power et al., 2016) that fire has been a persistent feature of the eastern Chiquitano dry forest where it meets the Pantanal wetlands throughout the Holocene. As the charcoal record at Laguna Mandioré does not appear to be strongly correlated with climatic factors, it is possible that humans may have caused some of the burning in the catchment. No crop indicators such as Zea mays or Cucurbita were found in the Laguna Mandioré vegetation record, but this is not evidence of human absence. Indeed, FEM observed petroglyphs along the shoreline of Laguna La Gaiba that extend below the waterline during the dry season, demonstrating human presence at a time when lake level was lower than in the present day, potentially during the mid-Holocene. Additionally midden and cave sites from across the Pantanal suggest hunter-fishergatherer communities were present in the region from 5000 cal yr BP (Bespalez, 2015). However, the paucity of charcoal records in the Chiquitano region, particularly at the local scale, precludes investigation of the role of humans in influencing the fire regime at present (Maezumi et al., 2018).

\section{Dry forest-upland savannah ecotone at Laguna Mandioré}

The abundance of the savannah tree Curatella americana increases markedly during the mid-Holocene drier climatic period, suggesting an increase in upland savannah in the catchment of Laguna Mandioré. Although Curatella americana trees can grow on raised islands (e.g., termite mounds) within the wetlands of the Pantanal, no other taxa typical of these forested islands within the wetlands of the Pantanal (such as Vochysia [Alho, 2005]) were detected in the pollen record. Furthermore, as Curatella americana pollen is poorly dispersed, it is likely to be a local signal, and given that the Mandiore 5 core site is located close to the base of the Amolar hills, the most parsimonious explanation is a downslope expansion of upland savannah on the Amolar hills during the drier period. The increase in $\delta^{13} \mathrm{C}$ during the midHolocene suggests an increase in $\mathrm{C}_{4}$ vegetation in the catchment (Meyers and Teranes, 2001; Pessenda et al., 1998; Fornace et al., 2016), which supports the interpretation of increasing upland savannah during this period. This is likely to be a terrestrial signal, as there is also an increase in the $\mathrm{C} / \mathrm{N}$ ratio during the mid-Holocene, indicating greater terrestrial and reduced algal inputs to the lake sediment during this time (Meyers and Teranes, 2001; Fig. 10). This interpretation is supported by climate and vegetation modelling of the midHolocene period, which suggests a weaker South American summer monsoon and drier climate during the mid-Holocene leading to a shift in species composition and increase in fragmentation of the forest at ecotones (Maksic et al., 2019).

The peak in charcoal concentration around $8000 \mathrm{cal}$ yr BP occurs just before the increase in Curatella americana pollen and the shift in $\delta^{13} \mathrm{C}$ (Fig. 10). This charcoal peak could indicate an increase in fire in the upland savannah that could have reinforced the climate-driven expansion of upland savannah at the expense of dry forest and a shift in the ecotone. The charcoal could also have been transported from fires within the semideciduous dry forest or dried-out areas of the Pantanal, where occasional fires are known to occur (Oliveira et al., 2014). As the majority of the particles were between 100 and $180 \mu \mathrm{m}$, they are likely to have been transported by wind from the same catchment as the wind-dispersed pollen found in the lake sediment. The pollen record predominantly reflects the dry forest and upland savannah at the Amolar hills ecotone, so it is therefore likely that the charcoal record largely represents fire within these ecosystems.

The expansion of upland savannah at the expense of dry forest would have shifted the ecotone between upland savannah and dry forest down the slopes of the Amolar hills towards lower-elevation areas previously covered by dry forest. This ecotone shift disproves our hypothesis that dry forest-upland savannah ecotones would be static in the face of climatic changes due to their overriding edaphic controls. At Laguna Mandioré, as precipitation decreases during the mid-Holocene, the interaction between drought and fire overrides the edaphic constraints on dry forest distribution and allows the expansion of the upland savannah into deeper, more fertile soils. The mechanism for the shifting of the ecotone and encroachment of upland savannah into dry forest may involve fire as an initial disturbance agent, opening up the canopy and allowing upland savannah to establish and then preventing the reestablishment of closed-canopy forest (Oliveras and Malhi, 2016; Cardoso et al., 2018). This suggests that both climate and fire are important drivers of vegetation change at the dry forest-upland savannah ecotone, which indicates that while climate is the primary driver of floristic change within the dry forest, this relationship does not apply to biome turnover at the dry forestupland savannah ecotone.

The decrease in Curatella americana pollen and $\delta^{13} \mathrm{C}$ from 3600 cal yr BP (Fig. 10) reflect the reduced extent of upland savannah and upslope shift of the dry forest-upland savannah ecotone to its present position on the slopes of the Amolar hills (Fig. 2). This fits with the timing of precipitation increase 
in the late Holocene suggested by regional palaeoclimate records, including lake levels at Laguna Titicaca (Baker et al., 2001), $\delta^{18} \mathrm{O}$ records from the Andes (Bird et al., 2011), and sponge and diatom records from the Pantanal (Guerreiro et al., 2017). This precipitation increase is also reflected in the vegetation at Laguna Mandioré by peak aquatic plant pollen abundance (Fig. 6), the decline in $\mathrm{C} / \mathrm{N}$, and high $\mathrm{Rb} / \mathrm{K}$ and $\mathrm{Re} / \mathrm{K}$ ratios (Fig. 9). These vegetation changes fit with the regional pattern of forest expansion at the southwestern edge of the Amazon during the late Holocene, as shown by palaeo-vegetation records from Lagunas Chaplin and Bella Vista (Mayle et al., 2000; Burbridge et al., 2004) to the north and Laguna Yaguarú (Taylor et al., 2010) to the west of Laguna Mandioré.

\section{Implications for future climate change}

Climate models predict reduced precipitation for tropical South America in the coming century, with a longer dry season over much of southern Amazonia and up to 30\% reduction in precipitation over the Pantanal basin (Marengo et al., 2014, 2016; Boisier et al., 2015; Duffy et al., 2015; Sánchez et al., 2015). The long-term implications of reduced precipitation in the Chiquitano dry forest that we have observed from the mid-Holocene record at Laguna Mandioré are threefold.

First, the dry forest is vulnerable to the impact of drought at its ecotones with upland savannah. Reduction in precipitation at these ecotones can lead to an encroachment of upland savannah at the expense of dry forest, potentially through the interacting effects of reduced precipitation and fire. However, the encroachment of upland savannah is likely to be locally restricted to the forest edges, as the ecotone shift was not detected in the pollen record at Laguna La Gaiba $20 \mathrm{~km}$ to the north, and the majority of the Laguna Mandiore pollen catchment is still dominated by dry forest during the mid-Holocene. Therefore, the level of precipitation reduction during the mid-Holocene only instigated local-scale biome turnover at the ecotone, not a regional-scale replacement of dry forest by savannah.

Second, the dry forest still dominates the majority of the Laguna Mandioré catchment during the mid-Holocene drier period and maintains closed-canopy forest away from the ecotone with upland savannah. However, there are floristic changes within the dry forest, with a shift towards more drought-tolerant tree taxa such as Anadenanthera and Astronium. The implications of this shift for conservation of the dry forest under climate change depend on the objective of the conservation strategy. If the objective is to preserve the forest biome, for carbon stocks or otherwise, then the results of this study bode well for the future, in that a future drier climate will not cause a regional-scale biome shift to a savannah ecosystem. However, if the conservation of particular taxa is a key goal, then conservation strategies may need to be targeted towards managing their likely changes in distribution and abundance expected under a future drier climate; for example, connectivity measures, such as the maintenance of corridors and buffer zones to allow for future climate-induced range shifts in these taxa, may be needed.

Third, the Mandiore charcoal record strengthens the evidence that fire has been a persistent feature of the eastern edge of the Chiquitano dry forest, where it meets the Pantanal wetlands, throughout the Holocene (Power et al., 2016). This challenges the widely held assumption among many ecologists (e.g., Pennington et al., 2009), based on presence of firesusceptible taxa such as Cereus (Cactaceae), that this ecosystem is inherently susceptible to fire. However, it is possible that the frequency of fires observed today, most of which are caused by humans clearing land for agriculture, significantly exceeds the fire frequency through most of the Holocene (Power et al., 2016). If so, despite its resilience to Holocene fires, this threatened forest may be especially susceptible to future burning if increased fragmentation of the forest and anthropogenic ignitions are coupled with increased drought and higher temperatures, which would be expected to lead to future fires of significantly greater magnitude and/or frequency than Holocene baseline conditions.

\section{CONCLUSIONS}

The long-term impacts of drier climatic conditions during the mid-Holocene on the Bolivian tropical dry forest did not entail large-scale dieback of the forest and replacement by upland savannah. The first hypothesis, that the dry forestupland savannah ecotone would not shift during the midHolocene drier period due to overriding edaphic controls, was not supported. A local-scale shift in the position of the forest-savannah ecotone was found, whereby upland savannah expanded downslope at the expense of the dry forest. This demonstrates that climatic changes can override edaphic constraints at dry forest-upland savannah ecotones. The second hypothesis, that the dry forest would maintain a closed canopy throughout the mid-Holocene drier period with some floristic changes, was supported in the forest away from the ecotone, where floristic composition shifted towards more drought-tolerant tree taxa such as Anadenanthera and Astronium. The third hypothesis, that the root cause of vegetation changes in the dry forest during the Holocene is climate rather than fire, was supported, as there was no clear interaction between the fire regime and the shift in floristic composition within the dry forest. However, at the dry forest-upland savannah ecotone, the proximate (rather than root) cause may have been fire, whereby a drier climate increased flammability, leading to localised upland savannah expansion.

These findings have implications for the conservation of tropical dry forest in South America under future climate change. While there was no evidence for large-scale dieback of the dry forest under mid-Holocene levels of drought, there was a shift in floristic composition, with some taxa increasing significantly at the expense of others. This implies that conservation policy involving corridors and buffer zones will be needed to enable movement of species under future 
climate change. Furthermore, the dry forest has been shown to be vulnerable to upland savannah encroachment at its ecotones under past drier climatic conditions, with fire potentially reinforcing the expansion of savannah. This finding may have particularly important implications for the cerrado biome, which encompasses a range of savannah physiognomies, including mosaics of dry forest and terra firme savannah (Oliveira Filho and Ratter, 2002). In these landscapes, dry forest islands provide habitat heterogeneity both structurally and taxonomically, including supporting mammal populations that are mostly associated with or restricted to forest patches (Klink and Machado, 2005). Under drier climatic conditions, these small islands of dry forest could be under threat from savannah encroachment. As precipitation is reduced with future climate change, the impacts of human land use such as forest fragmentation and use of fires may exacerbate the encroachment of savannah. These complex interactions will be important in determining the vulnerability of the tropical dry forest under future climate change.

\section{ACKNOWLEDGMENTS}

We thank José Iriarte from the Department of Archaeology, University of Exeter, UK, for providing training in phytolith preparation and identification and contributing herbarium material to begin the University of Reading tropical phytolith reference collection. We thank the authorities of San Matias National Park and Otuquis National Park for permission to core Laguna Mandioré and Timothy J. Killeen and the Muséo de Historia Natural Noel Kempff Mercado (MHNNKM), Santa Cruz, Bolivia, for logistical support. Rene Guilllen, William Gosling, and Phil Metcalfe assisted with the fieldwork. We acknowledge the Royal Botanic Gardens Edinburgh and the MHNNKM for herbarium material to build up the pollen reference collection. Funding was provided by the University of Reading for a PhD studentship (HJP), the National Geographic Society and the Royal Society for fieldwork funding (FEM), and the Natural Environment Research Council (NERC) Radiocarbon Facility for 6 AMS ${ }^{14} \mathrm{C}$ dates (allocation number 2038.1016) (FEM and HJP). We would also like the thank the editors and reviewers for many useful and thoughtful comments which helped greatly improve this manuscript.

\section{REFERENCES}

Alho, C.J.R., 2005. The Pantanal. In: Fraser, L.H., Keddy, P.A. (Eds.), The World's Largest Wetlands: Ecology and Conservation. Cambridge University Press, Cambridge, pp. 203-271.

Baker, P.A., Seltzer, G.O., Fritz, S.C., Dunbar, R.B., Grove, M.J., Tapia, P.M., Cross, S.L., Rowe, H.D., Broda, J.P., 2001. The history of South American tropical precipitation for the past 25,000 years. Science 291, 640-643.

Banda-R, K., Delgado-Salinas, A., Dexter, K.G., Linares-Palomino, R., Oliveira-Filho, A., Prado, D., Pullan, M., et al., 2016. Plant diversity patterns in neotropical dry forests and their conservation implications. Science 353, 1383-1387.

Bennett, K.D., 1996. Determination of the number of zones in a biostratigraphical sequence. New Phytologist 132, 155-170.

Bespalez, E., 2015. Arqueologia e história indígena no Pantanal. Estudos Avançados 29, 45-86.
Bird, B.W., Abbott, M.B., Rodbell, D.T., Vuille, M., 2011. Holocene tropical South American hydroclimate revealed from a decadally resolved lake sediment $\delta 18 \mathrm{O}$ record. Earth and Planetary Science Letters 310, 192-202.

Birks, H.J.B., Line, J.M., 1992. The use of rarefaction analysis for estimating palynological richness from Quaternary pollenanalytical data. The Holocene 2, 1-10.

Blaauw, M., Christen, J.A., 2011. Flexible paleoclimate age-depth models using an autoregressive gamma process. Bayesian Analysis 6, 457-474.

Boisier, J.P., Ciais, P., Ducharne, A., Guimberteau, M., 2015. Projected strengthening of Amazonian dry season by constrained climate model simulations. Nature Climate Change 5, 656-660.

Boutton, T.W., 1996. Stable carbon isotope ratios of soil organic matter and their use as indicators ofvegetation and climate change. In: Boutton, T.W., Yamasak, S. (Eds.), Mass Spectrometry of Soils. Dekker, New York, pp. 47-82.

Boyd, W.E., Lentfer, C.J., Torrence, R., 1998. Phytolith analysis for wet tropics environment: methodological issues and implications for the archaeology of Garua Island, West New Britain, Papua New Guinea. Palynology 22, 213-228.

Burbridge, R.E., Mayle, F.E., Killeen, T.J., 2004. Fifty-thousand-year vegetation and climate history of Noel Kempff Mercado National Park, Bolivian Amazon. Quaternary Research 61, 215-230.

Burn, M.J., Mayle, F.E., 2008. Palynological differentiation between genera of the Moraceae family and implications for Amazonian palaeoecology. Review of Palaeobotany and Palynology 149, 187-201.

Cardoso, A.W., Oliveras, I., Abernethy, K.A., Jeffery, K.J., Lehmann, D., Edzang Ndong, J., McGregor, I., Belcher, C.M., Bond, W.J., Malhi, Y.S., 2018. Grass species flammability, not biomass, drives changes in fire behavior at tropical forest-savanna transitions. Frontiers in Forests and Global Change 1, 6.

Carson, J.F., Watling, J., Mayle, F.E., Whitney, B.S., Iriarte, J., Prumers, H., Soto, J.D., 2015. Pre-Columbian land use in the ring-ditch region of the Bolivian Amazon. The Holocene 25, 1285-1300.

Colinvaux, P.A., Oliveira, P.E. de, Patiño, J.E.M., 1999. Amazon Pollen Manual and Atlas. Harwood Academic, Amsterdam.

Cruz, F.W., Vuille, M., Burns, S.J., Wang, X., Cheng, H., Werner, M., Lawrence Edwards, R., Karmann, I., Auler, A.S., Nguyen, H., 2009. Orbitally driven east-west antiphasing of South American precipitation. Nature Geoscience 2, 210-214.

DeFries, R., Hansen, A., Newton, A.C., Hansen, M.C., 2004. Increasing isolation of protected areas in tropical forests over the past twenty years. Ecological Applications 15, 19-26.

Dickau, R., Whitney, B.S., Iriarte, J., Mayle, F.E., Soto, J.D., Metcalfe, P., Street-Perrott, F.A., Loader, N.J., Ficken, K.J., Killeen, T.J., 2013. Differentiation of neotropical ecosystems by modern soil phytolith assemblages and its implications for palaeoenvironmental and archaeological reconstructions. Review of Palaeobotany and Palynology 193, 15-37.

Dubs, B., 1992. Observations on the differentiation of woodland and wet savanna habitats in the Pantanal of Mato Grosso, Brazil. In: Furley, P.A., Proctor, J., Ratter, J.A. (Eds.), Nature and Dynamics of Forest-Savanna Boundaries. Chapman \& Hall, London, pp. 431-449.

Duffy, P.B., Brando, P., Asner, G.P., Field, C.B., 2015. Projections of future meteorological drought and wet periods in the Amazon. Proceedings of the National Academy of Sciences USA 112, 201421010. 
Faegri, K., Iversen, J., 1989. Textbook of Pollen Analysis. John Wiley and Sons Ltd, Chichester.

Fornace, K.L., Whitney, B.S., Galy, V., Hughen, K.A., Mayle, F.E., 2016. Late Quaternary environmental change in the interior South American tropics: new insight from leaf wax stable isotopes. Earth and Planetary Science Letters 438, 75-85.

Francus, P., Lamb, H., Nakagawa, T., Marshall, M., Brown, E., Members, S. 2006 P., 2009. The potential of high-resolution $\mathrm{X}$-ray fluorescence core scanning: applications in paleolimnology. PAGES News 17, 93-95.

Gentry, A.H., 1995. Diversity and floristic composition of neotropical dry forests. In: Bullock, S.H., Mooney, H.A., Medina, E. (Eds.), Seasonally Dry Tropical Forests. Cambridge University Press, Cambridge, pp. 146-194.

Gosling, W.D., Mayle, F.E., Tate, N.J., Killeen, T.J., 2009. Differentiation between Neotropical rainforest, dry forest, and savannah ecosystems by their modern pollen spectra and implications for the fossil pollen record. Review of Palaeobotany and Palynology 153, 70-85.

Grimm, E.C., 1987. CONISS: a FORTRAN 77 program for stratigraphically constrained cluster analysis by the method of incremental sum of squares. Computers \& Geosciences 13, 13-35.

Guerreiro, R.L., McGlue, M.M., Stone, J.R., Bergier, I., Parolin, P., Silva Caminha, S.A.F. da, Warren, L. V., Assine, M.L., 2017.

Paleoecology explains Holocene chemical changes in lakes of the Nhecolandia (Pantanal-Brazil). Hydrobiologia 815 (1), $1-19$.

Hamilton, S.K., 2002. Hydrological controls of ecological structure and function in the Pantanal wetland (Brazil). In: The Ecology of South American Rivers and Wetlands. IAHS Special Publication No. 6. International Association of Hydrological Sciences, Wallingford, UK, 133-158.

Harris, D., Horwath, W.R., Kessel, C. van, 2001. Acid fumigation of soils to remove carbonates prior to total organic carbon or carbon-13 isotopic analysis. Soil Science Society of America Journal 65, 1853-1856.

Heiri, O., Lotter, A.F., Lemcke, G., 2001. Loss on ignition as a method for estimating organic and carbonate content in sediments: reproducibility and comparability of results. Journal of Paleolimnology 25, 101-110.

Hilje, B., Calvo-Alvarado, J., Jiménez-Rodríguez, C., Sánchez-Azofeifa, A., 2015. Tree species composition, breeding systems, and pollination and dispersal syndromes in three forest successional stages in a tropical dry forest in Mesoamerica. Tropical Conservation Science 8, 76-94.

Iriarte, J., Paz, E.A., 2009. Phytolith analysis of selected native plants and modern soils from southeastern Uruguay and its implications for paleoenvironmental and archeological reconstruction. Quaternary International 193, 99-123.

Janzen, D., 1988. Tropical dry forests. The most endangered major tropical ecosystem. In: Wilson, E.O. (Ed.), Biodiversity. National Academy of Sciences/Smithsonian Institution, Washington DC, pp. 130-137.

Jardim, A., Killeen, T.J., Fuentes, A., 2003. Introduction. In: Rumiz, D.I. (Ed.), Guía de Los Árboles y Arbustos Del Bosque Seco Chiquitano, Bolivia. Fundacíon Amigos de la Naturaleza Noel Kempff (FAN), Santa Cruz, Bolivia, pp. 1-25.

Jones, H.T., Mayle, F.E., Pennington, R.T., Killeen, T.J., 2011. Characterisation of Bolivian savanna ecosystems by their modern pollen rain and implications for fossil pollen records. Review of Palaeobotany and Palynology 164, 223-237.
Juggins, S., 2016. C2 Version 1.7: software for ecological and palaeoecological data analysis and visualisation [computer software]. University of Newcastle, Newcastle-upon-Tyne, UK.

Juggins, S., 2017. rioja: analysis of Quaternary science data. R package version 0.9-15.1 [computer software]. University of Newcastle, Newcastle-upon-Tyne, UK.

Killeen, T.J., Chavez, E., Pena-Claros, M., Toledo, M., Arroyo, L., Caballero, J., Correa, L., et al., 2006. The Chiquitano dry forest, the transition between humid and dry forest in easterm lowland Bolivia. In: Pennington, T.R., Lewis, G. P., Ratter, J. A. (Eds.), Neotropical Savannahs and Seasonally Dry Forests: Plant Diversity, Biogeography and Conservation. Taylor \& Francis, pp. 213233. Boca Raton, Florida.

Killeen, T.J., Schulenberg, T.S., 1998. A Biological Assessment of Parc Nacional Noel Kempff Mercado, Bolivia. RAP Working Paper 10. Conservation International, Washington, DC.

Klink, C.A., Machado, R.B., 2005. Conservation of the Brazilian cerrado. Conservation Biology 19, 707-713.

Kondo, R., Childs, C., Atkinson, L., 1994. Opal phytoliths of New Zealand. Manaaki Press, Lincoln, New Zealand.

Lu, H., Liu, K.B., 2003. Phytoliths of common grasses in the coastal environments of southeastern USA. Estuarine, Coastal and Shelf Science 58, 587-600.

Maezumi, S.Y., Whitney, B.S., Mayle, F.E., Gregorio de Souza, J., Iriarte, J., 2018. Reassessing climate and pre-Columbian drivers of paleofire activity in the Bolivian Amazon. Quaternary International 488, 81-94.

Maksic, J., Shimizu, M.H., Oliveira, G.S. de, Venancio, I.M., Cardoso, M., Ferreira, F.A., 2019. Simulation of the Holocene climate over South America and impacts on the vegetation. The Holocene 29(2), 287-299.

Malhi, Y., Aragao, L.E.O.C., Galbraith, D., Huntingford, C., Fisher, R., Zelazowski, P., Sitch, S., McSweeney, C., Meir, P., 2009. Exploring the likelihood and mechanism of a climate-change-induced dieback of the Amazon rainforest. Proceedings of the National Academy of Sciences USA 106, 20610-20615.

Malhi, Y., Roberts, J.T., Betts, R.A, Killeen, T.J., Li, W., Nobre, C.A, 2008. Climate change, deforestation, and the fate of the Amazon. Science 319, 169-172.

Marengo, J., Alves, L., Torres, R., 2016. Regional climate change scenarios in the Brazilian Pantanal watershed. Climate Research 68, 201-213.

Marengo, J., Chou, SC, Torres, R., Giarolla, A., Alves, L., Lyra, A., 2014. Climate Change in Central and South America: Recent Trends, Future Projections, and Impacts on Regional Agriculture. CGIAR Research Program on Climate Change, Agriculture and Food Security (CCAFS). Copenhagen, Denmark.

Marsh, E.J., Bruno, M.C., Fritz, S.C., Baker, P., Capriles, J.M., Hastorf, C.A., 2018. IntCal, SHCal, or a mixed curve? Choosing a14C calibration curve for archaeological and paleoenvironmental records from tropical South America. Radiocarbon 60, 925-940.

Mayle, F.E., Burbridge, R., Killeen, T.J., 2000. Millennial-scale dynamics of southern Amazonian rain forests. Science 290, 2291-2294.

McGlue, M.M., Silva, A., Corradini, F.A., Zani, H., Trees, M.A., Ellis, G.S., Parolin, M., Swarzenski, P.W., Cohen, A.S., Assine, M.L., 2011. Limnogeology in Brazil's "forgotten wilderness": a synthesis from the large floodplain lakes of the Pantanal. Journal of Paleolimnology 46, 273-289. 
McGlue, M.M., Silva, A., Zani, H., Corradini, F.A., Parolin, M., Abel, E.J., Cohen, A.S., et al., 2012. Lacustrine records of Holocene flood pulse dynamics in the upper Paraguay River watershed (Pantanal wetlands, Brazil). Quaternary Research 78, 285-294.

Mercader, J., Bennett, T., Esselmont, C., Simpson, S., Walde, D., 2009. Phytoliths in woody plants from the Miombo woodlands of Mozambique. Annals of Botany 104, 91-113.

Mercader, J., Bennett, T., Esselmont, C., Simpson, S., Walde, D., 2011. Soil phytoliths from miombo woodlands in Mozambique. Quaternary Research 75, 138-150.

Metcalfe, S.E., Whitney, B.S., Fitzpatrick, K.A., Mayle, F.E., Loader, N.J., Street-Perrott, F.A., Mann, D.G., 2014. Hydrology and climatology at Laguna La Gaiba, lowland Bolivia: complex responses to climatic forcings over the last 25000 years. Journal of Quaternary Science 29, 289-300.

Meyers, P., Teranes, J., 2001. Sediment Organic Matter. Tracking Environmental Change Using Lake Sediments. Vol. 2, Physical and Geochemical Methods. Kluwer Academic, Dordrecht, Netherlands.

Novello, V.F., Cruz, F.W., Vuille, M., Stríkis, N.M., Edwards, R.L., Cheng, H., Emerick, S. et al., 2017. A high-resolution history of the South American monsoon from last glacial maximum to the Holocene. Scientific Reports 7, 44267.

Nunes da Cunha, C., Junk, W.J., Leitão Filho, H.D.F., 2007. Woody vegetation in the Pantanal of Mato Grosso, Brazil: a preliminary typology. Amazoniana 19, 159-184.

Oksanen, J., Blanchet, F.G., Friendly, M., Kindt, R., Legendre, P., McGlinn, D., Minchin, P.R., et al., 2018. vegan: community ecology package. R package version 2.5-2 [computer software]. Natural History Museum, Helsinki, Finland.

Oliveira, M.T. de, Damasceno-Junior, G.A., Pott, A., Paranhos Filho, A.C., Suarez, Y.R., Parolin, P., 2014. Regeneration of riparian forests of the Brazilian Pantanal under flood and fire influence. Forest Ecology and Management 331, 256-263.

Oliveira Filho, A.T., Ratter, J.A., 2002. Vegetation physiognomies and woody flora of the Cerrado Biome. In: Oliveira, P.S., Marquis, R.J. (Eds.), The Cerrados of Brazil. Columbia University Press, New York, pp. 91-120.

Oliveras, I., Malhi, Y., 2016. Many shades of green: the dynamic tropical forest-savannah transition zones. Philosophical Transactions of the Royal Society of London B 371, 20150308.

Olson, D.M., Dinerstein, E., Wikramanayake, E.D., Burgess, N.D., Powell, G.V.N., Underwood, E.C., D'amico, J.A., et al., 2001. Terrestrial ecoregions of the world: a new map of life on Earth. Bioscience 51, 933-938.

Pennington, R.T., Lavin, M., Oliveira-Filho, A., 2009. Woody plant diversity, evolution, and ecology in the tropics: perspectives from seasonally dry tropical forests. Annual Review of Ecology, Evolution, and Systematics 40, 437-457.

Pennington, R.T., Prado, D.E., Pendry, C.A., 2000. Neotropical seasonally dry forests and Quaternary vegetation changes. Journal of Biogeography 27, 261-273.

Pessenda, L.R., Gouveia, S.M., Aravena, R., Gomes, B.M., Boulet, R., Ribeiro, A.S., 1998. 14C dating and stable carbon isotopes of soil organic matter in forest-savanna boundary areas in the southern Brazilian Amazon region. Radiocarbon 40(2), 1013-1022.

Piperno, D.R., 2006. Phytoliths: A Comprehensive Guide for Archeologists and Paleoecologists. AltaMira Press, Lanham, MD.

Piperno, D.R., Pearsall, D.M., 1998a. The Origins of Agriculture in the Lowland Neotropics. Academic Press, New York.
Piperno, D.R., Pearsall, D.M., 1998b. The Silica Bodies of Tropical American Grasses: Morphology, Taxonomy, and Implications for Grass Systematics and Fossil Phytolith Identification. Smithsonian Contributions to Botany 1-40. Smithsonian Institution Press, Washington, DC.

Power, M.J., Whitney, B.S., Mayle, F.E., Neves, D.M., Boer, E.J. de, Maclean, K.S., 2016. Fire, climate and vegetation linkages in the Bolivian Chiquitano seasonally dry tropical forest. Philosophical Transactions of the Royal Society of London B 371, 20150165.

Prado, L.F., Wainer, I., Chiessi, C.M., Ledru, M.P., Turcq, B., 2013. A mid-Holocene climate reconstruction for eastern South America. Climate of the Past 9, 2117-2133.

Prance, G.T., Schaller, G.B., 1982. Preliminary study of some vegetation types of the Pantanal, Mato Grosso, Brazil. Brittonia 34, 228.

Rasbold, G.G., McGlue, M.M., Stevaux, J.C., Parolin, M., Silva, A., Bergier, I., 2019. Sponge spicule and phytolith evidence for Late Quaternary environmental changes in the tropical Pantanal wetlands of western Brazil. Palaeogeography, Palaeoclimatology, Palaeoecology 518, 119-133.

Ratter, J.A., Pott, A., Pott, V.J., Nunes da Cunha, C., Haridasan, M., 1988. Observations on woody vegetation types in the Pantanal and at Corumbá, Brazil. Notes from the Royal Botanic Garden, Edinburgh 45, 503-525.

Reese, C.A., Liu, K.B., Thompson, L.G., 2013. An ice-core pollen record showing vegetation response to Late-glacial and Holocene climate changes at Nevado Sajama, Bolivia. Annals of Glaciology 54, 183-190.

Reich, P.B., Borchert, R., 1984. Water stress and tree phenology in a tropical dry forest in the lowlands of Costa Rica. Journal of Ecology 72,61 .

Reimer, P.J., Bard, E., Bayliss, A., Beck, J.W., Blackwell, P.G., Ramsey, C.B., Buck, C.E., et al., 2013. IntCal13 and Marine13 radiocarbon age calibration curves 0-50,000 Years cal BP. Radiocarbon 55, 1869-1887.

Ricketson, J., 2001. Sparganiaceae bur-reed family. Journal of the Arizona-Nevada Academy of Science 33, 65-68.

Roubik, D., Moreno, P., 1991. Pollen and Spores of Barro Colorado Island. Monographs in Systematic Botany, Volume 36. Missouri Botanical Garden, St. Louis.

Runge, F., 1999. The opal phytolith inventory of soils in central Africa-quantities, shapes, classification, and spectra. Review of Palaeobotany and Palynology 107, 23-53.

Sánchez, E., Solman, S., Remedio, A.R.C., Berbery, H., Samuelsson, P., Rocha, R.P. Da, Mourão, C., et al., 2015. Regional climate modelling in CLARIS-LPB: a concerted approach towards twentyfirst century projections of regional temperature and precipitation over South America. Climate Dynamics 45, 2193-2212.

Sarmiento, G., Monasterio, M., 1975. A critical consideration of the environmental conditions associated with the occurrence of savanna ecosystems in tropical America. In: Golley, F.B., Medina, E. (Eds.), Tropical Ecological Systems. Ecological Studies (Analysis and Synthesis) 11. Springer, Berlin, pp. 223-250.

Seltzer, G., Rodbell, D., Burns, S., 2000. Isotopic evidence for late Quaternary climatic change in tropical South America. Geology 28, 35-38.

Taylor, Z.P., Horn, S.P., Mora, C.I., Orvis, K.H., Cooper, L.W., 2010. A multi-proxy palaeoecological record of late-Holocene forest expansion in lowland Bolivia. Palaeogeography, Palaeoclimatology, Palaeoecology 293, 98-107. 
Thompson, L.G., 1998. A 25,000-year tropical climate history from Bolivian ice cores. Science 282, 1858-1864.

Wallis, L., 2003. An overview of leaf phytolith production patterns in selected northwest Australian flora. Review of Palaeobotany and Palynology 125, 201-248.

Watling, J., Iriarte, J., 2013. Phytoliths from the coastal savannas of French Guiana. Quaternary International 287, 162-180.

Watling, J., Iriarte, J., Whitney, B.S., Consuelo, E., Mayle, F.E., Castro, W., Schaan, D., Feldpausch, T.R., 2016. Differentiation of neotropical ecosystems by modern soil phytolith assemblages and its implications for palaeoenvironmental and archaeological reconstructions II: southwestern Amazonian forests. Review of Palaeobotany and Palynology 226, 30-43.

Whitlock, C., Larsen, C., 2001. Charcoal as a fire proxy. In: Smol, J.P., Birks, H.J.B., Last, W.M. (Eds.), Tracking Environmental Change Using Lake Sediments. Vol. 3, Terrestrial, Algal, and Siliceous Indicators. KluwerAcademic Publishers, Dordrecht, Netherlands.
Whitney, B.S., Dickau, R., Mayle, F.E., Soto, J.D., Iriarte, J., 2013. Pre-Columbian landscape impact and agriculture in the Monumental Mound region of the Llanos de Moxos, lowland Bolivia. Quaternary Research 80, 207-217.

Whitney, B.S., Mayle, F.E., 2012. Pediastrum species as potential indicators of lake-level change in tropical South America. Journal of Paleolimnology 47, 601-615.

Whitney, B.S., Mayle, F.E., Burn, M.J., Guillén, R., Chavez, E., Pennington, R.T., 2014. Sensitivity of Bolivian seasonally-dry tropical forest to precipitation and temperature changes over glacial-interglacial timescales. Vegetation History and Archaeobotany 23, 1-14.

Whitney, B.S., Mayle, F.E., Punyasena, S.W., Fitzpatrick, K.A., Burn, M.J., Guillen, R., Chavez, E., Mann, D., Pennington, R.T., Metcalfe, S.E., 2011. A 45kyr palaeoclimate record from the lowland interior of tropical South America. Palaeogeography, Palaeoclimatology, Palaeoecology 307, 177-192. 